\title{
The distribution of runs of homozygosity in the genome of river and swamp buffaloes reveals a history of adaptation, migration and crossbred events
}

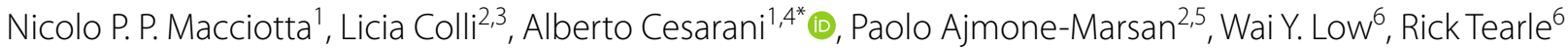
and John L. Williams 2,6

\begin{abstract}
Background: Water buffalo is one of the most important livestock species in the world. Two types of water buffalo exist: river buffalo (Bubalus bubalis bubalis) and swamp buffalo (Bubalus bubalis carabanensis). The buffalo genome has been recently sequenced, and thus a new $90 \mathrm{~K}$ single nucleotide polymorphism (SNP) bead chip has been developed. In this study, we investigated the genomic population structure and the level of inbreeding of 185 river and 153 swamp buffaloes using runs of homozygosity $(\mathrm{ROH})$. Analyses were carried out jointly and separately for the two buffalo types.

Results: The SNP bead chip detected in swamp about one-third of the SNPs identified in the river type. In total, $18,116 \mathrm{ROH}$ were detected in the combined data set (17,784 SNPs), and 16,251 of these were unique. ROH were present in both buffalo types mostly detected ( 59\%) in swamp buffalo. The number of ROH per animal was larger and genomic inbreeding was higher in swamp than river buffalo. In the separated datasets (46,891 and 17,690 SNPs for river and swamp type, respectively), 19,760 and 10,581 ROH were found in river and swamp, respectively. The genes that map to the $\mathrm{ROH}$ islands are associated with the adaptation to the environment, fitness traits and reproduction.

Conclusions: Analysis of $\mathrm{ROH}$ features in the genome of the two water buffalo types allowed their genomic characterization and highlighted differences between buffalo types and between breeds. A large ROH island on chromosome 2 was shared between river and swamp buffaloes and contained genes that are involved in environmental adaptation and reproduction.
\end{abstract}

\section{Background}

The domestic water buffalo represents a fundamental livestock resource for rural populations in many areas of the world, providing milk, meat and traction power. This species is also farmed in intensive dairy systems $[1,2]$ and is most famous for the production of mozzarella cheese, which has a high market value. In the last 50 years, the

\footnotetext{
*Correspondence: acesarani@uniss.it

${ }^{1}$ Dipartimento di Agraria, Università degli Studi di Sassari, Sassari, Italia

Full list of author information is available at the end of the article
}

world buffalo stock has shown a huge increase, from $88,321,807$ in 1961 to $200,967,747$ heads in 2017 [3], although there are large regional variations. The largest increases in number of buffaloes have occurred in India, Pakistan, and China, whereas the largest relative increase is found in Italy and Brazil ( $>200 \%$ ).

Two types of water buffalo exist: the river buffalo (Bubalus bubalis bubalis) and the swamp buffalo (Bubalus bubalis carabanensis). However, it is still under discussion if they should be considered as two distinct

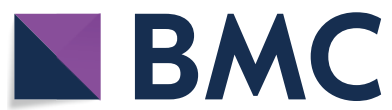

(c) The Author(s) 2021. This article is licensed under a Creative Commons Attribution 4.0 International License, which permits use, sharing, adaptation, distribution and reproduction in any medium or format, as long as you give appropriate credit to the original author(s) and the source, provide a link to the Creative Commons licence, and indicate if changes were made. The images or other third party material in this article are included in the article's Creative Commons licence, unless indicated otherwise in a credit line to the material. If material is not included in the article's Creative Commons licence and your intended use is not permitted by statutory regulation or exceeds the permitted use, you will need to obtain permission directly from the copyright holder. To view a copy of this licence, visit http://creativeco mmons.org/licenses/by/4.0/. The Creative Commons Public Domain Dedication waiver (http://creativecommons.org/publicdomain/ zero/1.0/) applies to the data made available in this article, unless otherwise stated in a credit line to the data. 
species, subspecies, or ecotypes. The two buffalo types have a different number of chromosomes due to a tandem fusion between chromosomes 4 and 9 in the swamp buffalo, which results in 50 and 48 chromosomes in the river and swamp buffalo, respectively [4]. They can interbreed and their crosses $(2 \mathrm{n}=49)$ are generally fertile [5], although some authors have suggested that the occurrence of unbalanced gametes may reduce fertility [6]. A number of ancient and recent events of admixture between the two types has been recorded [7]. River buffaloes are farmed from India and Pakistan to South-East and South Europe, North Africa and South America, whereas swamp buffaloes are mostly found in East and South East Asia.

Two domestication events occurred in water buffalo about 7000 years ago, on the Indian sub-continent for river buffalo and eastern Asia for swamp buffalo $[8,9]$. River and swamp buffaloes exhibit ecological and behavioral differences and are characterized by distinct biodiversity patterns. The river type consists of breeds that show distinct phenotypes as a result of selection, whereas the swamp type is represented mostly by local and unselected populations that are adapted to specific environments [7].

The water buffalo genome was recently sequenced by an International Consortium [10] and a higher quality genome assembly was released in February 2019 [11] with associated annotations (https://www.ncbi.nlm.nih. gov/genome/annotation_euk/Bubalus_bubalis/101/).

During the sequencing project, a medium-density $90 \mathrm{~K}$ SNP bead chip was developed in collaboration with Affymetrix (Axiom) using single nucleotide polymorphism (SNP) positions that were based on the Bos taurus reference sequence [12]. This $90 \mathrm{~K}$ chip has facilitated studies for the detection of candidate genes for milk production [2, 13-15], characterization of breeds, identification of signatures of selection [16], and investigation of the genetic histories of river and swamp populations [7]. Most of SNPs on the buffalo $90 \mathrm{~K}$ Axiom SNP chip are now annotated based on the high-quality buffalo genome sequence.

Classical population genetic approaches that are used to study biodiversity, demography, population structure, and inbreeding, can be extended by investigating the distribution of runs of homozygosity ( $\mathrm{ROH}) . \mathrm{ROH}$ are continuous stretches of homozygous genotypes that are found along the genome [17]. The proportion of the genome that carries $\mathrm{ROH}$ is an indicator of the actual inbreeding level of individuals and populations, whereas pedigree information estimates the expected level of inbreeding $[18,19]$. Moreover, the length of $\mathrm{ROH}$ is an indicator of the history of inbreeding events: long $\mathrm{ROH}$ are evidence of recent inbreeding and short $\mathrm{ROH}$ are indicators of ancient inbreeding [18, 19]. $\mathrm{ROH}$ can also result from artificial or natural selection, i.e. homozygous genotypes arise from the fixation of favorable alleles at selected loci and from the action of the genomic hitchhiking in surrounding regions. A ROH-based genomic relationship matrix implemented in a genomic best linear unbiased prediction (GBLUP) model allows the prediction of breeding values [20]. $\mathrm{ROH}$ are also used to detect selective sweeps in which alleles have become fixed [21, 22], and to map recessive alleles [23]. Recently, $\mathrm{ROH}$ distribution was investigated in river buffalo to study their genomic inbreeding and scan the genome for $\mathrm{ROH}$ islands [24, 25].

Here, we report the distribution and features of $\mathrm{ROH}$ in river and swamp buffalo populations, and use the information for an in-depth genomic investigation of domestic water buffalo to elucidate the genomic structure of different breeds and populations.

\section{Methods \\ Data}

The dataset consisted of genotypes for 185 river and 153 swamp buffaloes from 15 river and 13 swamp breeds or populations (Table 1). Animals were sampled during the buffalo genome sequencing project by the partners of the International Buffalo Consortium [12] between years 2011 and 2012, before Directive 2010/63/EU came into force (i.e., 1 January 2013). All experimental procedures complied with the former EU Directive 86/609/ EEC, according to which approval from dedicated animal welfare/ethics committee was not necessary. The permission to carry out the sampling at each farm was obtained directly from the owners. All the samples were collected during routine veterinary checks and in accordance with local/national regulations and ethical rules in force at the time of sampling.

All the animals were genotyped with the $90 \mathrm{~K}$ Affymetrix Axiom ${ }^{\circledR}$ Buffalo Genotyping Array at the Affymetrix laboratory (Santa Clara, CA, USA). The array was originally developed based on the Bos taurus sequence [12]. In the present work, we remapped the markers to the latest version of the buffalo genome assembly [11]. Since the SNP array was developed mainly from sequence data of river type buffaloes, it is moderately affected by ascertainment bias $(\mathrm{AB})$ when it is used to genotype swamp buffalo individuals, as described in a previous study [7]. For this reason, we built and analyzed three datasets: (i) a complete dataset (ALL_DATA) that included all river and swamp animals and was used to compare the two water buffalo types, and (ii) two type-specific datasets that contain only polymorphic SNPs and animals from either buffalo type (RIVER_DATA and SWAMP_DATA) and that 


\begin{tabular}{|c|c|c|c|}
\hline Breed/population & Country & Symbol & $\begin{array}{l}\text { Number } \\
\text { of animals }\end{array}$ \\
\hline & River type & & \\
\hline Murrah & Brazil & RIVBR_MUR & 30 \\
\hline Colombian & Colombia & RIVCO & 12 \\
\hline Egyptian & Egypt & RIVEG & 15 \\
\hline Azari & Azerbaijan & RIVIR_AZA & 9 \\
\hline Khuzestani & Iran & RIVIR_KHU & 10 \\
\hline Mazandarani & Iran & RIVIR_MAZ & 8 \\
\hline Mediterranean & Italy & RIVIT_MED & 30 \\
\hline Mediterranean & Mozambique & RIVMZ & 7 \\
\hline Murrah & Bulgaria & RIVPH_BU & 8 \\
\hline Murrah & India (Philippines) & RIVPH_IN & 4 \\
\hline Aza Kheli & Pakistan & RIVPK_AZK & 3 \\
\hline Kundhi & Pakistan & RIVPK_KUN & 10 \\
\hline Nili-Ravi & Pakistan & RIVPK_NIL & 15 \\
\hline Mediterranean & Romania & RIVRO & 9 \\
\hline \multirow[t]{2}{*}{ Anatolian } & Turkey & RIVTR_ANA & 15 \\
\hline & Swamp type & & \\
\hline Enshi & China & SWACN_ENS & 15 \\
\hline Fuling & China & SWACN_FUL & 15 \\
\hline Guizhou & China & SWACN_GUI & 11 \\
\hline Hunan & China & SWACN_HUN & 14 \\
\hline Yangzou & China & SWACN_YAN & 12 \\
\hline Yibin & China & SWACN_YIB & 15 \\
\hline Java & Indonesia & SWAIN_JAV & 12 \\
\hline Nusa tenggara & Indonesia & SWAIN_NUT & 7 \\
\hline Sumatra & Indonesia & SWAIN_SUM & 8 \\
\hline \multirow[t]{4}{*}{ South Sulawesi } & Indonesia & SWAIN_SUW & 10 \\
\hline & Philippines & SWAPH & 21 \\
\hline & Thailand & SWATH_THS & 5 \\
\hline & Thailand & SWATH_THT & 8 \\
\hline
\end{tabular}

were used to analyze within-type differences between breeds or populations.

Initially, all SNPs and animals were quality-controlled as a single set. An animal was discarded if its individual call rate was lower than 0.95 and a SNP was discarded if the call rate was lower than 0.95 , and the minor allele frequency (MAF) was lower than 0.01. Additional filtering steps were carried out separately for each of the three datasets. For the ALL_DATA set, only SNPs that were polymorphic in the swamp buffaloes were retained, according to the approach followed by [7] to reduce the impact of ascertainment bias. In the RIVER_DATA and SWAMP_DATA sets, SNPs that deviated statistically from Hardy Weinberg equilibrium expectations $(\mathrm{P}<0.00001)$ were also discarded. After quality control,
17,784 SNPs were retained in the ALL_DATA set, and 46,891 and 17,690 SNPs were retained in the RIVER DATA and SWAMP_DATA sets, respectively. MAF statistics and linkage disequilibrium (LD) plots for the two types are in (see Additional file 1: Figure S1, Additional file 2 Table S1).

\section{Detection of runs of homozygosity}

Defining the settings for the detection of $\mathrm{ROH}$ is a crucial point because of their effect on the results. The detection of $\mathrm{ROH}$ was carried out separately for each of the three datasets using the Zanardi pipeline [26]. In the present work, we adopted criteria that were previously used on a medium-density cattle SNP panel [27]: (i) minimum number of SNPs included in a $\mathrm{ROH}=15$; (ii) minimum $\mathrm{ROH}$ length $=1 \mathrm{Mb}$; (iii) maximum distance between two consecutive SNPs in a $\mathrm{ROH}=1 \mathrm{Mb}$; and (iv) no heterozygous or missing genotypes were allowed. Sliding windows were not used for the detection of $\mathrm{ROH}$. A recent paper on Iranian river buffalo $\mathrm{ROH}$ [24] set a more stringent criterion for the minimum number of SNPs included in a $\mathrm{ROH}$ but allowed for the presence of one heterozygous or one missing genotype in a $\mathrm{ROH}$. Given the huge reduction in SNP density in the ALL_DATA set, a less stringent threshold for the minimum number of SNPs was adopted in this study but no heterozygous or missing genotypes were allowed.

The following statistics were calculated: number of ROH per animal (n_ROH), average $\mathrm{ROH}$ length (1_ROH), $\mathrm{ROH}$ distribution across five classes of length that are usually considered for cattle and sheep $(1<\mathrm{Mb} \leq 2$; $2<\mathrm{Mb} \leq 4 ; 4<\mathrm{Mb} \leq 8 ; 8<\mathrm{Mb} \leq 16 ;$ and $\mathrm{Mb}>16)$. The total number of $\mathrm{ROH}$ could include exactly the same chromosomal segment repeated in different animals. Thus, a unique $\mathrm{ROH}$ was defined as a homozygous segment that starts and finishes at exactly the same precise chromosomal positions [28]. We also checked the distribution of unique $\mathrm{ROH}$ among breeds and animals.

The $\mathrm{ROH}$ count per SNP $\left(\mathrm{SNP}_{\mathrm{ROH}}\right)$, i.e., the number of animals that have a given SNP in a $\mathrm{ROH}$ was also calculated [23]. A SNP that has an $\mathrm{SNP}_{\mathrm{ROH}}$ value in the top $1 \%$ of the distribution was considered as significant [28, 29]. Thus, based on $\mathrm{SNP}_{\mathrm{ROH}}$, genomic regions that contained uninterrupted sequences of significant SNPs were defined as $\mathrm{ROH}$ islands.

The $\mathrm{ROH}$-based inbreeding coefficient $\left(\mathrm{F}_{\mathrm{ROH}}\right)$ for each animal was calculated as the ratio between the length of the genome covered by $\mathrm{ROH}$ and the total genome length [30]. Finally, a $\mathrm{ROH}$ based-genomic relationship matrix was calculated $\left(\mathbf{G}_{\mathbf{R O H}}\right)$ by coding SNP genotypes as follows: $0=$ heterozygous; $1=$ homozygous not included in a $\mathrm{ROH}$; and $2=$ homozygous included in a $\mathrm{ROH}$. SNP coding was based on their presence/absence in $\mathrm{ROH}$ 
longer than $4 \mathrm{Mb} . \mathbf{G}_{\mathbf{R O H}}$ was then calculated according to [31] for all three datasets.

The functions of the genes included in $\mathrm{ROH}$ islands were investigated, with particular attention to regions where significant markers according to their $\mathrm{SNP}_{\mathrm{ROH}}$ were located. Annotated genes were retrieved from the National Centre for Biotechnology Information (NCBI) databases.

In order to compare the results of $\mathrm{ROH}$ detection, particularly their chromosomal location and the length of $\mathrm{ROH}$ islands, with more widely used parameters, we calculated the Wright fixation index $\left(\mathrm{F}_{\mathrm{ST}}\right)$ for the ALL DATA set using the equation proposed by [32]. River and swamp buffaloes were compared. $\mathrm{F}_{\mathrm{ST}}$ interpretation was improved by removing noise from the raw signals with a locally weighed scatterplot smoothing (LOWESS) procedure [33]. A threshold based on $\mathrm{F}_{\mathrm{ST}}$ distribution was adopted [33-35], and SNPs that were three standard deviations from the mean were considered relevant.

\section{Statistical analysis}

The effects of buffalo type, breed and chromosome on $\mathrm{ROH}$ length and $\mathrm{n} \_\mathrm{ROH}$ were tested. Because of the markedly skewed distribution of these two variables, a generalized mixed linear model with a lognormal distribution was used to perform a statistical analysis. In particular, $\mathrm{ROH}$ length in the ALL_DATA set was analyzed with the following model:

$$
\mathrm{y}=\mu+\mathrm{TYPE}+\mathrm{CHROM}+\mathrm{BREED}(\text { TYPE })+\text { animal }+\mathrm{e},
$$

where $\mathrm{y}$ is the $\mathrm{ROH}$ length, $\mu$ is the overall mean, TYPE is the fixed effect of buffalo type (river vs swamp), CHROM is the fixed effect of the chromosome (24 levels), BREED(TYPE) is the fixed effect of the breed nested within type, animal is the random effect of the animal (338 levels), and e is the random residual. The two random effects were assumed to be normally distributed with parameters $\left(\mathbf{0}, \mathbf{I} \sigma_{a}^{2}\right)$ and $\left(\mathbf{0}, \mathbf{I} \sigma_{e}^{2}\right)$, where $\mathbf{I}$ is an identity matrix and $\sigma_{a}^{2}$ and $\sigma_{e}^{2}$ are variance components associated with the animal and residual random effects, respectively. The repeatability, i.e., the contribution of the animal variance to the total variance was calculated as: $\mathrm{r}_{\mathrm{p}}=\sigma_{a}^{2} /\left(\sigma_{a}^{2}+\sigma_{e}^{2}\right)$. This parameter expresses the average correlation between 1_ROH values within animals.

The number of $\mathrm{ROH}$ per animal (one measure per individual) was analyzed with a generalized linear model that included the fixed effects of type and breed nested within type.

In the RIVER_DATA and SWAMP_DATA sets, ROH length was analyzed with the following generalized mixed linear model:

$$
\mathrm{y}=\mu+\mathrm{BREED}+\mathrm{CHROM}+\text { animal }+\mathrm{e},
$$

where each term is as defined in the previous model. The number of $\mathrm{ROH}$ was analyzed with a model that included the fixed effect of the breed. Generalized mixed linear model analysis was performed using the SAS PROC GLIMMIX (SAS Inc, 2011).

The relationship between the occurrence of an SNP in a $\mathrm{ROH}$ and the type of buffalo was assessed in the ALL_ DATA set using a logistic regression model. For each individual, the SNP was coded as 1 if included or 0 if not included in a run. This binary variable was analyzed with the following logistic regression model:

$$
\log \frac{p}{1-p}=\beta_{0}+\beta_{\text {type }}
$$

where $p$ is the probability of a SNP to be included in a $\mathrm{ROH} ; \beta_{0}$ is the intercept; and $\beta_{\text {type }}$ is the fixed effect for the type (river vs swamp). The logistic regression was performed using the SAS PROC LOGISTIC.

\section{Results}

ALL_DATA set

$\mathrm{ROH}$ were found in all breeds and populations for both water buffalo types, with $18,116 \mathrm{ROH}$ detected in the ALL_DATA dataset (Table 2). The largest number (about $59 \%$ of the $18,116 \mathrm{ROH}$ ) was detected in the swamp buffalo, whereas in river buffalo $\mathrm{ROH}$ were longer, but both these statistics varied a lot among populations (Table 2). In the ALL_DATA set, 16,251 ROH were unique. The $\mathrm{ROH}$ distribution across length classes had a negative exponential shape (Fig. 1), with the second smallest class, $2<\mathrm{Mb} \leq 4$, being the most abundant in both river and swamp buffaloes. $\mathrm{ROH}$ distribution among the chromosomes was proportional to their length for both buffalo types (see Additional file 3: Figure S2).

Swamp populations had more $\mathrm{ROH}$ per individual compared to river breeds (Fig. 2). The swamp population of the Indonesian island of Nusa Tenngara of Indonesia had the highest average $n \_$ROH (118.6) and the Indian Murrah river breed had the lowest (13.8). Among river buffaloes, the Mediterranean breed of Mozambique had the highest n_ROH (96.6). These figures were confirmed

Table 2 Basic statistics of ROH frequency and length for river and swamp buffaloe in the ALL_DATA set

\begin{tabular}{llll}
\hline Statistics & River & Swamp & All \\
\hline Total number of ROH & 7429 & 10,687 & 18,116 \\
$\begin{array}{l}\text { Total number of unique ROH } \\
\text { Average number of ROH per }\end{array}$ & 6712 & 9539 & 16,251 \\
$\quad \begin{array}{l}\text { animal } \\
\text { Average ROH length }\end{array}$ & $40 \pm 27$ & $70 \pm 33$ & $54 \pm 33$ \\
Average ROH count per SNP (\%) & $6.5 \pm 3.2$ & $9.4 \pm 5.1$ & $7.9 \pm 4.5$ \\
\hline
\end{tabular}




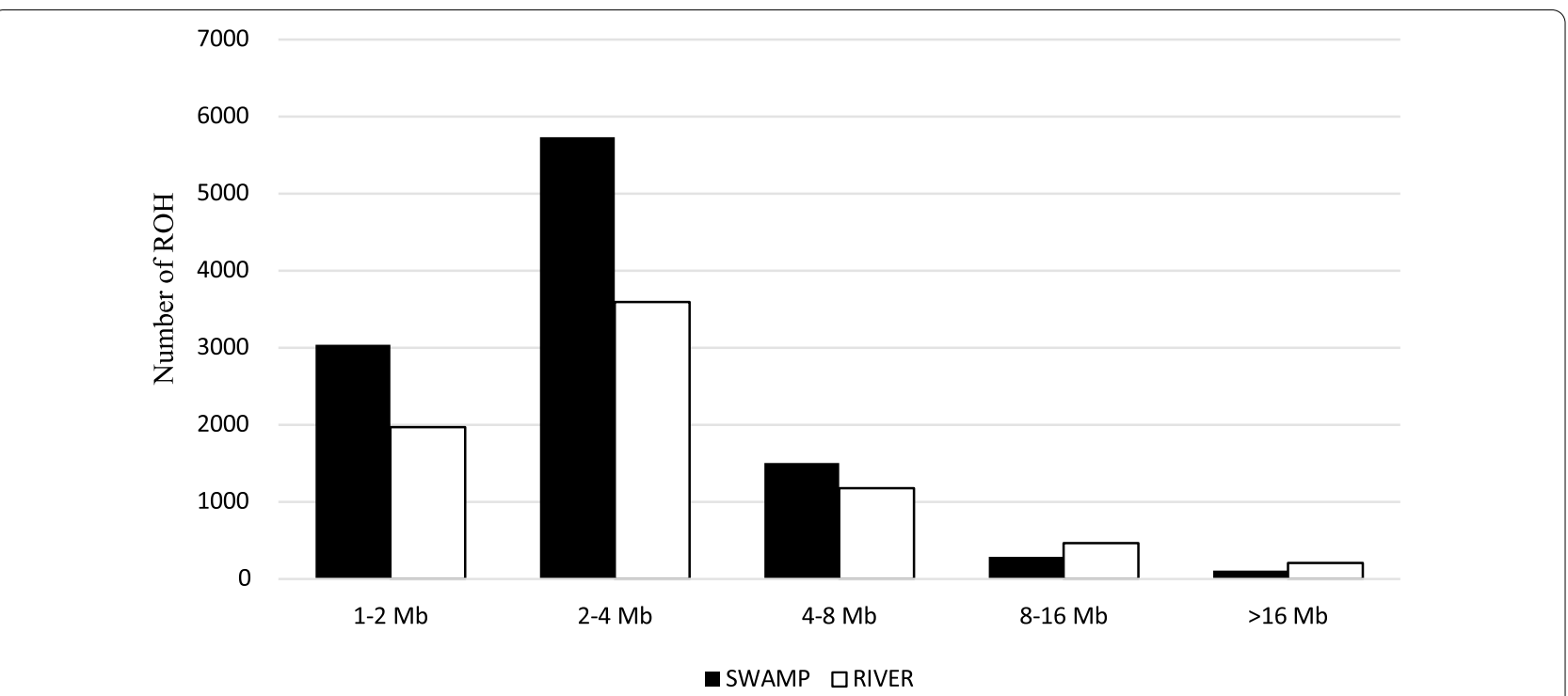

Fig. 1 Distribution of length classes of ROH. Frequency distribution of ROH across length classes in river (white bars) and swamp (black bars) buffalo

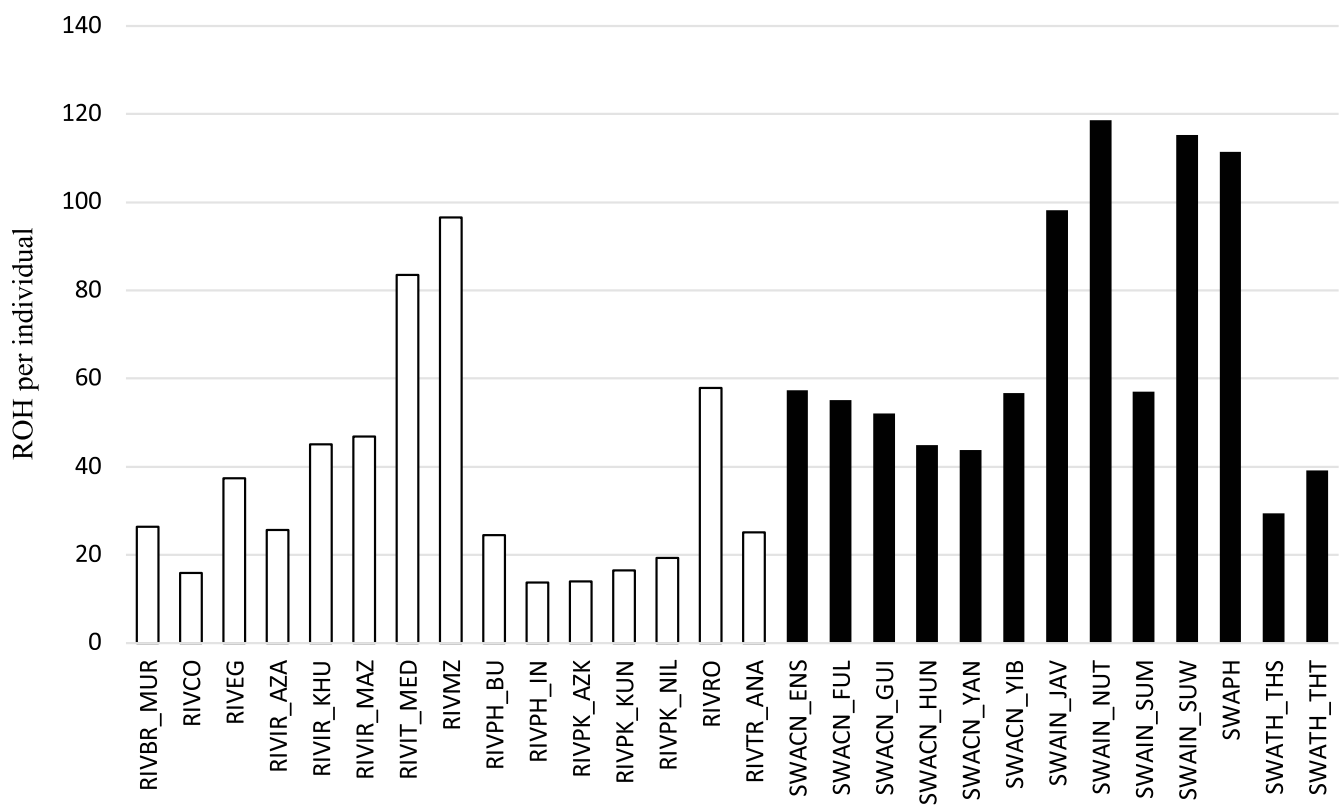

Fig. 2 Distribution of number of ROH. Distribution of the average number of ROH per animal in river (white bars) and swamp (black bars) buffalo populations

by the generalized mixed linear model analysis. The average $n \_$ROH was significantly affected by the type and the breed within type, with swamp buffaloes having the highest values (LSMean and SE $60.46 \pm 1.24$ vs $29.11 \pm 0.61$ ) compared to river buffaloes.

Average 1_ROH was generally larger in river buffalo breeds (Fig. 3), although the Thailand swamp population had the greatest average length $(6.5 \mathrm{Mb})$. The longest $\mathrm{ROH}(52.5 \mathrm{Mb}$ and 354 SNPs, respectively) was detected on Bubalus bubalis chromosome (BBU) 10 in an Indonesian Nusa Tenngara individual. The chromosomes with the largest average 1_ROH were BBU18 in river $(5.8 \mathrm{Mb})$ and BBU13 in swamp (4.1) buffalo, respectively (see Additional file 4: Figure 


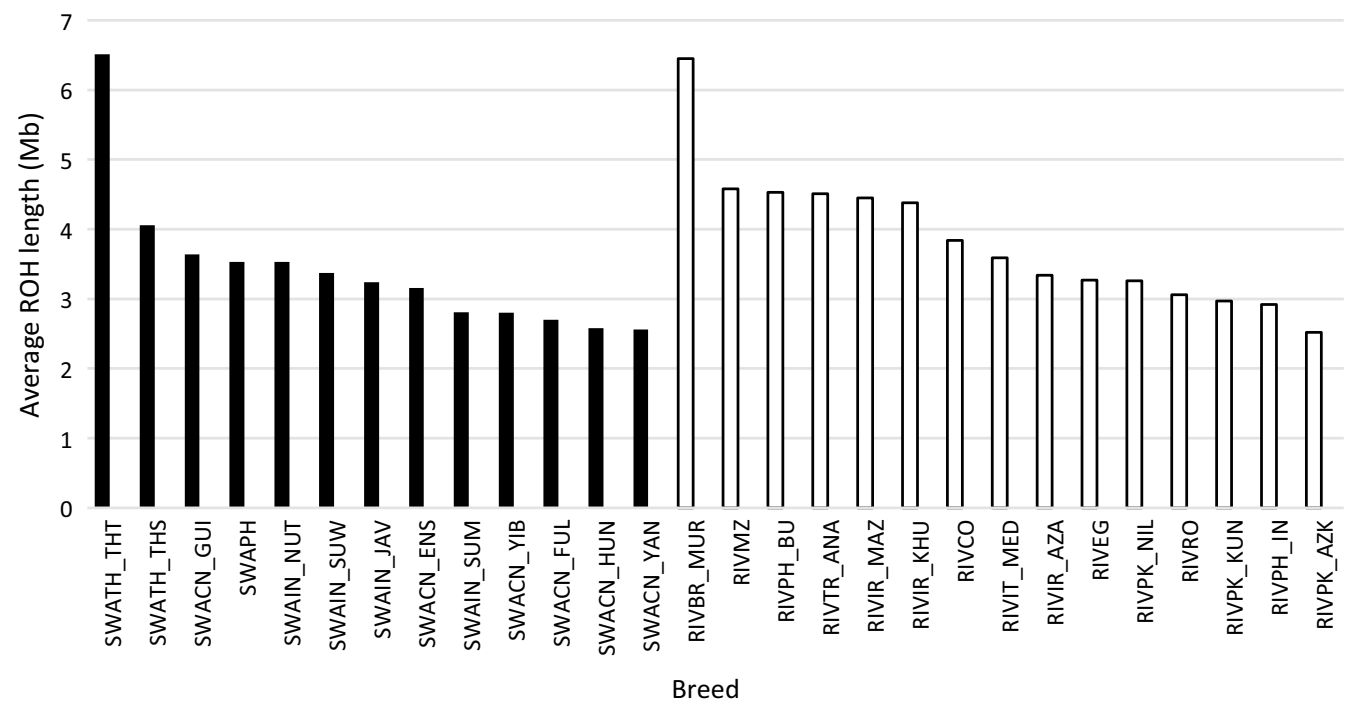

Fig. 3 Distribution of length of $\mathrm{ROH}$. Distribution of the average $\mathrm{ROH}$ length in river (white bars) and swamp (black bars) buffalo populations

Table 3 ROH-based coefficient of inbreeding in the two types of river buffalo calculated from the ALL_DATA set using different minimum thresholds of ROH length

\begin{tabular}{lll}
\hline Inbreeding coefficient & River buffalo & Swamp buffalo \\
\hline$F_{R O H}$ all & $0.06 \pm 0.05$ & $0.09 \pm 0.06$ \\
$F_{R O H}>2 \mathrm{Mb}$ & $0.06 \pm 0.05$ & $0.08 \pm 0.06$ \\
$F_{R O H}>4 \mathrm{Mb}$ & $0.04 \pm 0.04$ & $0.04 \pm 0.05$ \\
$F_{\mathrm{ROH}}>8 \mathrm{Mb}$ & $0.03 \pm 0.04$ & $0.03 \pm 0.05$ \\
\hline
\end{tabular}

S3). Type, breed within type, and chromosome significantly affected the 1_ROH $(P<0.001)$. The average values of $1 \_R O H$ were largest for river buffaloes (LSmean and SE Mb $2.87 \pm 0.05$ ) compared to swamp buffaloes $(2.67 \pm 0.04)$. Significant differences were also observed among chromosomes, breeds or populations and between types (data not shown). LSmeans was largest on BBU18 $(3.32 \pm 0.11)$ and smallest on BBU19 $(2.33 \pm 0.05)$. The repeatability for this trait was 0.08 .

Different $\mathrm{F}_{\mathrm{ROH}}$ values were obtained for the two buffalo types when all homozygous segments were considered (Table 3). Swamp populations tended to have higher $\mathrm{F}_{\mathrm{ROH}}$ with the highest values observed in the buffaloes from Indonesia, Thailand, and the Philippines (Fig. 4a). Chinese swamp buffaloes showed less variable $\mathrm{F}_{\mathrm{ROH}}$ values compared to other swamp populations. Among river buffaloes, $\mathrm{F}_{\mathrm{ROH}}$ was highest for the Mediterranean breed sampled in Mozambique (Fig. 4a) and lowest for those from Pakistan, which also showed the least variability in $\mathrm{F}_{\mathrm{ROH}}$. When only $\mathrm{ROH}$ longer than
$4 \mathrm{Mb}$ were used in the calculation, the levels of genomic inbreeding were similar between swamp and river buffaloes (Fig. 4b). The $\mathrm{F}_{\mathrm{ROH}}$ pattern among breeds or populations within a type was similar to that observed using all the $\mathrm{ROH}$.

The most frequent $\mathrm{ROH}$, i.e. detected in nine animals, was located on BBU16 between 81.6 and $84.4 \mathrm{Mb}$ and was shared by individuals of both river and swamp buffaloes (see Additional file 5: Table S2). Another $\mathrm{ROH}$ located on BBU10 at $101 \mathrm{Mb}$ was also shared by both river and swamp buffaloes. Other frequent $\mathrm{ROH}$ were found in Chinese swamp buffalo populations, and in Italian and Mozambique river buffalo breeds. It is interesting to note that two $\mathrm{ROH}$ located on BBU2 at 49.1 and $50.8 \mathrm{Mb}$ and shared by Chinese and Indonesian swamp buffalo populations, overlapped largely with a third $\mathrm{ROH}$ located at $46.2 \mathrm{Mb}$ on BBU2 (see Additional file 5: Table S2).

The ROH count per SNP was larger in swamp than in river buffaloes. The largest $\mathrm{SNP}_{\mathrm{ROH}}$ value $(34 \%, 118$ out of 338 , i.e. 82 and 36 in swamp and river buffalo, respectively) was detected on BBU2 at about $50.8 \mathrm{Mb}$. In total, 176 SNPs, located on six chromosomes, exceeded the $99^{\text {th }}$ percentile threshold of the $\mathrm{SNP}_{\mathrm{ROH}}$ distribution and were considered as significant (Fig. 5). These most significant SNPs clustered in specific regions (Table 4), which were considered as $\mathrm{ROH}$ islands. The largest regions were located on BBU1 and BBU2. The functions of the genes that map to these regions were further investigated. Plotting $\mathrm{ROH}$ against chromosome position clearly shows the $\mathrm{ROH}$ islands that are shared by the two buffalo types: examples for BBU2, 4, and 19 are 
a SWATH_THS -
SWAPH -
SWAIN SUW SWAIN_SUM SWAIN_NUT SWAIN_JAV SWACN_YIB SWACN_Y̌AN SWACN HUN SWACN_GUI SWACN FUL D SWACN_ENS\& RIVTR_ANA ต RIVRO RIVPK_NIL RIVPK_KUNN -

RIVPK_AZKRIVPH_IN_RIVPH_BURIVMZ -

RIVIT_MED -

RIVIR_MAZ -

RIVIR_KHU -

RIVIR_AZA RIVEG RIVCO RIVBR_MUR 0.0

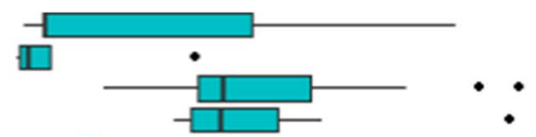

-11-

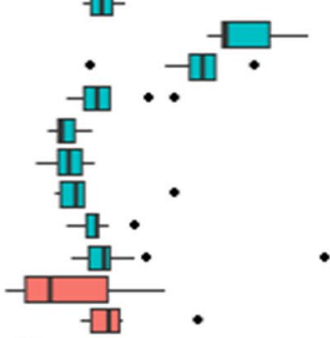

-15-

- ㄴ-

1 가

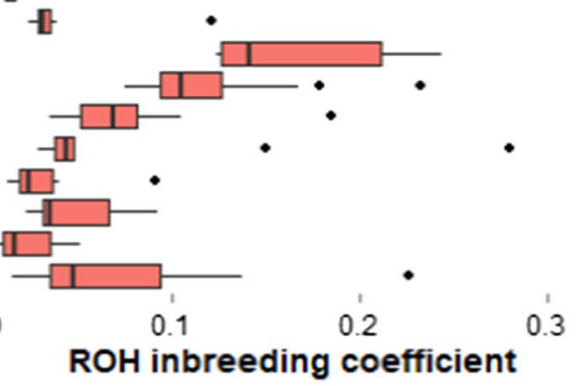

b

SWATH_THT -

SWATH_THS SW'APH -

SWAIN_SUW -

SWAIN_SUM -

SWAIN NUT -

SWAIN_JAV-

SWACN_YIB -

SWACN_YAN

SWACN HUN -

SWACN_GUI

SWACN_FUL

D SWACN_ENS

I RIVTR_ANA

m RIVRO -

RIVPK_NIL-

RIVPK_KUN

RIVPK_AZK-

RIVPH_IN_-

RIVPH_BU_RIVM

RIVIT_MED -

RIVIR MAZ -

RIVIR_KHU -

RIVIR AZA

RIVEG -

RIVCO -

RIVBR_MUR -

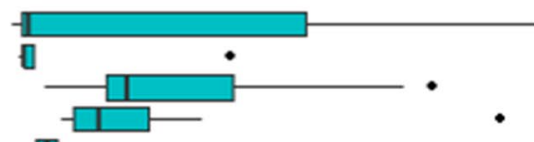

-11-
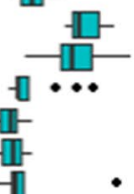

-II-
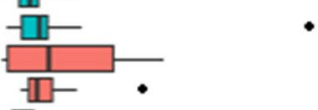

$-1+$

RIVER

-

SWAMP

\section{ROH inbreeding coefficient}

Fig. 4 Box-plot of ROH-based inbreeding. Box plot of the ROH-based inbreeding coefficient in different populations/breeds of river (red) and swamp (green), calculated using all the detected $\mathrm{ROH}(\mathbf{a})$ or $\mathrm{ROH}$ longer than $4 \mathrm{Mb}$ (b) 


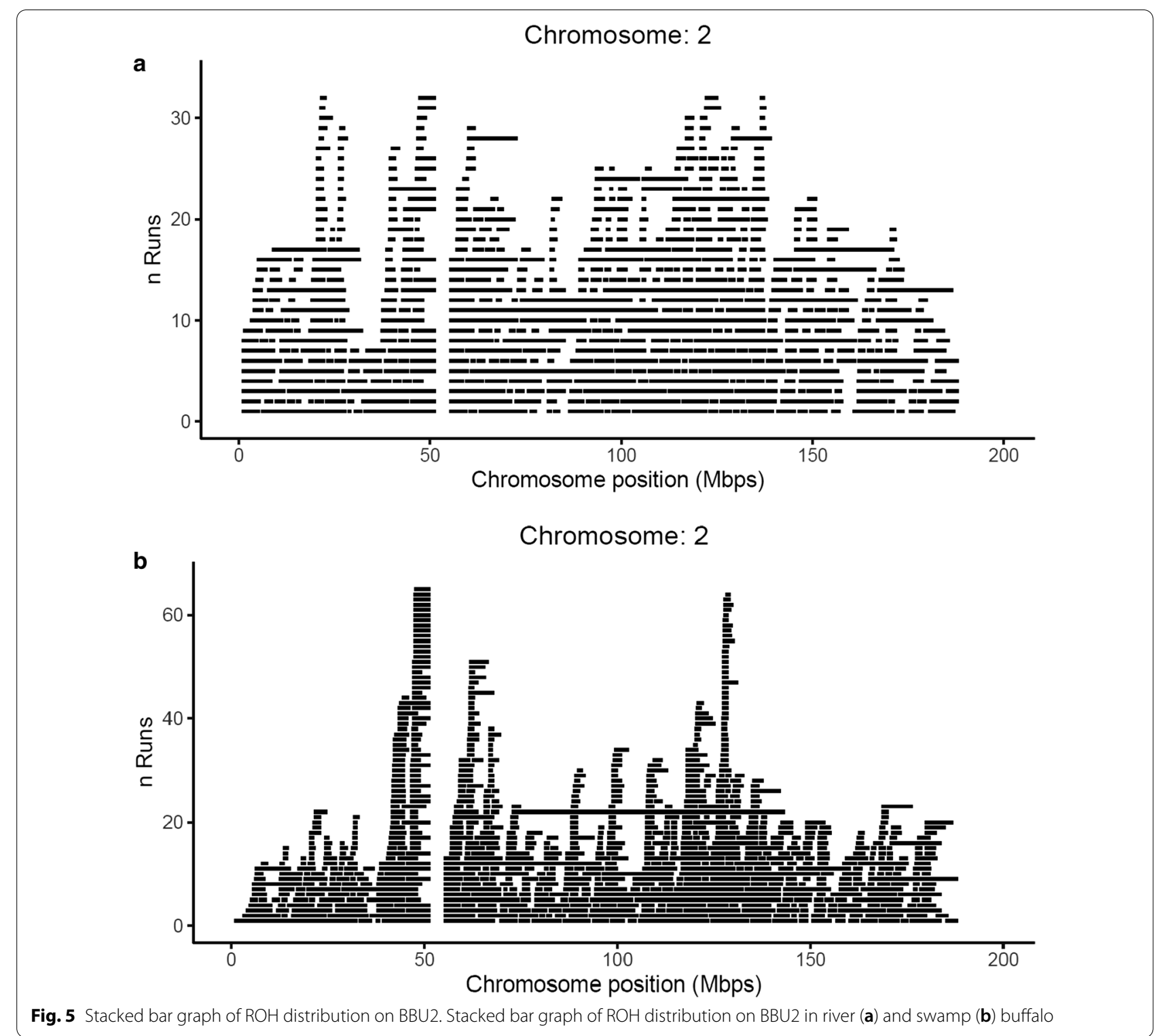

shown in Fig. 5 and (see Additional file 6: Figure S4 and Additional file 7: Figure S5), respectively.

The Manhattan plot of the pattern of LOWESS-corrected $\mathrm{F}_{\mathrm{ST}}$ values (see Additional file 8: Figure $\mathrm{S6}$ ) shows strong signals on BBU1, 2, 5, and 8, although 87 SNPs located on 18 chromosomes exceeded the threshold of three standard deviations from the mean. Of these 87 SNPs, 18 were located within $\mathrm{ROH}$ islands defined by $\mathrm{SNP}_{\mathrm{ROH}}$ (Table 4). Four of these SNPs were located between 112.98 and $113.65 \mathrm{Mb}$ on BBU1, 11 between 46.91 and $50.04 \mathrm{Mb}$ on BBU2 and three between 127.85 and 127.96 on BBU3. The average $\mathrm{F}_{\mathrm{ST}}$ of SNPs located within these $\mathrm{ROH}$ hotspots was higher than the average value of the corresponding chromosome (Table 4). Such differences were largest for the $\mathrm{ROH}$ islands located on BBU1 and for the first two on BBU2.

The results of the logistic regression highlighted significant differences $(\mathrm{P}<0.01)$ between river and swamp buffaloes in terms of the probability of a SNP to be included within a ROH $\left(P_{\text {RSNP_ROH }}\right)$ for 1876 of 17,784 SNPs. The overall average odds ratio (OR) was $1.73( \pm 1.37)$, which indicates that the $P_{\text {RSNP_ROH }}$ increases by about $70 \%$ from river to swamp buffalo. If only the 176 significant SNPs exceeding the 99th percentile of the $\mathrm{SNP}_{\mathrm{ROH}}$ distribution are considered, the average OR increases to $4.16( \pm 1.37)$, with a fourfold increase of $P_{\text {RSNP ROH }}$ in swamp compared to river. Although for most of the 176 significant SNPs the OR was higher than 2 , which means that $P_{\text {RSNP_ROH }}$ 
Table 4 Average $\mathrm{F}_{\mathrm{ST}}$, odd ratio and $\mathrm{SNP}_{\mathrm{ROH}}$ for the markers in the highlighted $\mathrm{ROH}$ islands

\begin{tabular}{|c|c|c|c|c|c|c|c|c|}
\hline \multicolumn{4}{|c|}{$\mathrm{ROH}$ island } & \multicolumn{2}{|l|}{ Average FST } & \multirow[t]{2}{*}{ Odds ratio } & \multicolumn{2}{|c|}{$\mathrm{SNP}_{\mathrm{ROH}}$} \\
\hline BBU & SNP & Start (Mb) & End (Mb) & $\mathrm{ROH}$ island & BBU & & RIV & SWA \\
\hline 1 & 20 & 11.01 & 12.43 & $0.46 \pm 0.06$ & $0.23 \pm 0.10$ & $9.98 \pm 2.67$ & 8.10 & 46.60 \\
\hline 1 & 21 & 112.56 & 115.20 & $0.49 \pm 0.06$ & $0.23 \pm 0.10$ & $5.27 \pm 0.92$ & 9.45 & 35.70 \\
\hline 2 & 39 & 46.77 & 57.78 & $0.44 \pm 0.13$ & $0.22 \pm 0.10$ & $3.38 \pm 1.07$ & 16.90 & 40.40 \\
\hline 2 & 7 & 61.45 & 62.32 & $0.40 \pm 0.08$ & $0.22 \pm 0.10$ & $3.10 \pm 0.53$ & 11.80 & 28.50 \\
\hline 2 & 9 & 120.40 & 121.17 & $0.32 \pm 0.07$ & $0.22 \pm 0.10$ & $1.99 \pm 0.24$ & 14.80 & 25.00 \\
\hline 2 & 18 & 127.15 & 128.80 & $0.36 \pm 0.13$ & $0.22 \pm 0.10$ & $3.22 \pm 0.55$ & 12.20 & 31.80 \\
\hline 4 & 13 & 114.43 & 117.05 & $0.28 \pm 0.05$ & $0.22 \pm 0.08$ & $2.02 \pm 0.21$ & 14.70 & 25.40 \\
\hline 7 & 11 & 53.00 & 53.70 & $0.26 \pm 0.02$ & $0.20 \pm 0.07$ & $0.74 \pm 0.05$ & 21.60 & 16.70 \\
\hline 17 & 13 & 50.71 & 51.62 & $0.34 \pm 0.02$ & $0.22 \pm 0.09$ & $1.63 \pm 0.46$ & 16.50 & 24.00 \\
\hline 19 & 20 & 51.52 & 52.86 & $0.36 \pm 0.05$ & $0.23 \pm 0.08$ & $1.70 \pm 0.39$ & 18.00 & 27.40 \\
\hline
\end{tabular}

$\mathrm{SNP}_{\mathrm{ROH}}=\mathrm{ROH}$ count per SNP

Table 5 Basic ROH statistics, and their frequency distribution across length classes in the RIVER_DATA and SWAMP_DATA sets

\begin{tabular}{lll}
\hline & RIVER_DATA & SWAMP_DATA \\
\hline Statistics & & \\
Total number of ROH & 19,760 & 10,581 \\
Total number of unique ROH & 18,152 & 9594 \\
Average number of ROH per animal & $107 \pm 58$ & $69 \pm 32$ \\
Average ROH length & $2.23 \pm 2.61$ & $3.31 \pm 3.55$ \\
Average ROH count per SNP (\%) & $9.6 \pm 4.7$ & $26.9 \pm 17.3$ \\
Distribution across length classes & & \\
1-2 Mb & $14,068(71.2 \%)$ & $2971(28.1 \%)$ \\
2-4 Mb & $3955(20.0 \%)$ & $5696(53.8 \%)$ \\
$4-8 \mathrm{Mb}$ & $1154(5.9 \%)$ & $1509(14.3 \%)$ \\
$8-16 \mathrm{Mb}$ & $440(2.2 \%)$ & $290(2.7 \%)$ \\
$>16 \mathrm{Mb}$ & $143(0.7 \%)$ & $115(1.1 \%)$ \\
\hline
\end{tabular}

is more than twice as high in swamp than in river buffalo, 42 of these SNPs exhibited values lower than 1.0, which indicates that, for these markers, the $P_{\mathrm{RSNP} \_\mathrm{ROH}}$ is higher in river than in swamp buffalo. Finally, all $\mathrm{ROH}$ islands except one showed average OR values higher than 1 (Table 4). The only ROH island that had an average OR lower than 1 was on BBU7.

\section{RIVER_DATA set}

In total, 19,760 ROH were detected in the RIVER_DATA set, most of which (>90\%) were unique (Table 5). The distribution of $\mathrm{ROH}$ across different length classes showed a negative exponential shape, but the most abundant class corresponded to the shortest length (Table 5). The number of $\mathrm{ROH}$ was largest in the Italian Mediterranean river buffalo breed and smallest in the Pakistani AzaKheli breed, although these breeds had the largest and the smallest sample size, respectively. Average $n \_R O H$ (219.86) was highest for the Mozambique breed and lowest for the Indian Murrah sampled in the Philippines (49.75). Generalized mixed model analysis confirmed these results. Differences in $\mathrm{n} \_\mathrm{ROH}$ between breeds $(\mathrm{P}<0.001)$ were significant with the largest LSmeans $(95.87 \pm 9.70)$ for the Mozambique buffaloes and the smallest $(13.38 \pm 2.07)$ for the Pakistani Aza-Kheli buffaloes. Most of the pairwise comparisons between breeds were highly significant.

The longest average 1_ROH was found in the Brazilian Murrah breed (3.22 Mb) and the shortest was in the Pakistani Aza-Kheli breed (1.53 Mb). The general pattern was similar to that observed in the ALL_DATA set. 1_ROH was significantly affected by breed and chromosome $(P<0.001)$, with the largest value found for the Brazilian Murrah breed (LSmean and SE Mb 2.07 \pm 0.05 ) and the smallest for the Pakistani Aza-Kheli breed (1.40 \pm 0.12 ). Pairwise comparisons highlighted significant differences between the Brazilian Murrah and all of the other breeds, except the Iranian Mazandarani and Mozambique breeds. BBU5 had the largest 1_ROH LSmean $(1.82 \pm 0.04)$ and BBU21 the smallest $(1.56 \pm 0.04)$. BBU2 was statistically different from BBU12, 17, and 19. The repeatability for this $\mathrm{ROH}$ characteristics was 0.05 .

The river buffalo individual with the largest number of $\mathrm{ROH}$ (274) belonged to the Mediterranean Mozambique breed and that with the smallest number (37) belonged to the Pakistani Aza-Kheli breed. The longest $(66.47 \mathrm{Mb})$ and shortest $(1 \mathrm{Mb}) \mathrm{ROH}$ were both found in Italian Mediterranean buffaloes, on BBU10 and BBU7, respectively. The most frequently detected $\mathrm{ROH}$, i.e. in nine animals of the Italian and Mozambique Mediterranean breeds, was located on BBU9 (see Additional file 9: Table S3). Four of the five most frequently shared $\mathrm{ROH}$ 
were found in the Mediterranean Italian river buffalo breed.

Inbreeding coefficients for river buffalo, calculated using different sets of $\mathrm{ROH}$ (Table 6), were similar to those obtained with the ALL_DATA set (Table 3), except for the value obtained when all $\mathrm{ROH}$ were used. The average inbreeding coefficient calculated using all $\mathrm{ROH}$ was largest for the Mediterranean Mozambique breed and lowest for the Pakistani breeds. The individual with the largest inbreeding coefficient (0.31) was an Iranian Khuzestani buffalo.

The average $\mathrm{SNP}_{\mathrm{ROH}}$ in the RIVER_DATA set was 17 $( \pm 8.7)$. In total, 432 SNPs exceeded the threshold of the $99^{\text {th }}$ percentile of the $\mathrm{SNP}_{\mathrm{ROH}}$ distribution. They were located on 16 chromosomes (see Additional file 10: Table S4) and clustered into $23 \mathrm{ROH}$ islands with a length ranging from 0.03 to $10.77 \mathrm{Mb}$. The $\mathrm{ROH}$ island detected on BBU2 between 49.7 and $54.8 \mathrm{Mb}$ largely overlapped with that observed in the ALL_DATA set.

\section{SWAMP_DATA set}

The number of $\mathrm{ROH}$ detected in swamp buffaloes was about half that found in river buffaloes (Table 5), although it should be noted that the SWAMP_DATA set comprised only about one-third of the SNPs in the RIVER_ DATA set. The SNPs included in the SWAMP_DATA set overlapped with those in the ALL_DATA set with a few exceptions due to independent pruning for missing data and MAF. For this reason, the results for $\mathrm{ROH}$ number and $\mathrm{ROH}$ features in swamp buffaloes obtained with the two datasets were very similar (Tables 2,5 ). The Philippine swamp buffalo population had the largest number of $\mathrm{ROH}$ (2322) and the Thailand population had the longest average $\mathrm{ROH}$ length $(2.35 \mathrm{Mb})$. The second shortest class of $\mathrm{ROH}$ was predominant in the swamp type with about $54 \%$ of the homozygous segments being in the $2<\mathrm{Mb} \leq 4$ class length (Table 5 ). The most frequently detected $\mathrm{ROH}$ (see Additional file 10: Table S4), i.e. in seven animals, were located on BBU1 at $11.0 \mathrm{Mb}$ and BBU2 at $50.8 \mathrm{Mb}$.

1_ROH was significantly affected by both population and chromosome $(\mathrm{P}<0.001)$. The swamp buffalo population of Thailand had the largest LSmean, which was

\begin{tabular}{|c|c|c|}
\hline Inbreeding coefficient & River & Swamp \\
\hline $\mathrm{F}_{\mathrm{ROH}}$ all & $0.09 \pm 0.06$ & $0.09 \pm 0.02$ \\
\hline $\mathrm{F}_{\mathrm{ROH}}>2 \mathrm{Mb}$ & $0.05 \pm 0.05$ & $0.08 \pm 0.06$ \\
\hline $\mathrm{F}_{\mathrm{ROH}}>4 \mathrm{Mb}$ & $0.03 \pm 0.04$ & $0.04 \pm 0.05$ \\
\hline $\mathrm{F}_{\mathrm{ROH}}>8 \mathrm{Mb}$ & $0.03 \pm 0.03$ & $0.03 \pm 0.05$ \\
\hline
\end{tabular}

statistically different from that of most of other groups (Mb $3.55 \pm 0.21$ ), and the Chinese Hunan swamp buffalo (Mb 2.35 \pm 0.10$)$ had the smallest LSmean. The repeatability of this $\mathrm{ROH}$ characteristic was 0.08 . n_ROH was affected by population, with the largest $(118.23 \pm 8.64)$ and smallest $(28.57 \pm 2.48)$ LS means found for Indonesian Nusa Tenggara and Thailand buffaloes, respectively. Pairwise comparisons mostly highlighted significant differences between Indonesian buffaloes and the other populations.

The Indonesian Nusa Tenggara population had the largest average inbreeding coefficient $(0.16 \pm 0.07)$ and the Chinese Yangzou population had the smallest $(0.04 \pm 0.01)$. The individual with the largest $\mathrm{F}_{\mathrm{ROH}}(0.32)$ was a Nusa Tenggara buffalo.

The average $\mathrm{SNP}_{\mathrm{ROH}}$ in the SWAMP_DATA set was 15 ( \pm 7.8$)$. One hundred and sixty-nine SNPs exceeded the threshold of the 99th percentile of the $\mathrm{SNP}_{\mathrm{ROH}}$ distribution and were located on six chromosomes (see Additional file 10: Table S4). Fourteen $\mathrm{ROH}$ islands were detected, ranging in size from $0.03 \mathrm{Mb}$ (2 SNPs) on BBU17 to $6.77 \mathrm{Mb}$ (and 33 SNPs) on BBU1. The three significant SNPs located on BBU8 were not considered because they were separated by more than $1 \mathrm{Mb}$ from each other. Most of the $\mathrm{ROH}$ islands detected in the SWAMP_DATA set coincided with those found in the ALL_DATA set and, to a lesser extent, in the RIVER DATA sets. The $\mathrm{ROH}$ island, located between 49 and $57 \mathrm{Mb}$ on BBU2 was common across all three datasets.

\section{Gene function analysis}

Because the $\mathrm{ROH}$ identified in the SWAMP_DATA set overlapped with those in the ALL_DATA set, we investigated the functions of the genes located in $\mathrm{ROH}$ islands for the ALL_DATA and RIVER_DATA sets only.

\section{ALL_DATA set}

Two large $\mathrm{ROH}$ hotspots were detected on BBU1 (Table 4), which harbor several annotated genes (see Additional file 11: Table S5). Four of the genes located in the first $\mathrm{ROH}$ (between 11.01 and $12.43 \mathrm{Mb}$ ) are associated with reproduction traits in several livestock species [36-39]: ADAM32, ADAM9, PLEKHA2 and FGFR1. The latter was also found within a $\mathrm{ROH}$ detected in Hanwoo, Black Angus and Holstein cattle [22]. The second largest $\mathrm{ROH}$ island on BBU1, located between 112.6 and 115.2 $\mathrm{Mb}$, also contains genes that have a role in livestock reproduction, i.e., ADCY2, KALRN, and IQCG [40]. The $\mathrm{ROH}$ island on BBU1 also contains the UMPS gene, which has been reported to be associated with feed efficiency in beef cattle [41].

The large $\mathrm{ROH}$ island located between 46.8 and $57.8 \mathrm{Mb}$ on BBU2 (Table 4) contains many annotated 
genes. Four of these genes are associated with reproduction traits: DST [42, 43], RAB23 [44], KHDRBS2 [45-47], and TUBGCP5 [48]. The ROH island on BBU2 also contains three genes that are involved in skin pigmentation and eye disorders: LGSN [49], OCA2 [50, 51], and HERC2 [52] and have been identified in selection signatures in buffalo [25] and in cattle [51]. Additional genes that map to this region are: $P T P N 18$, a gene involved in the regulation of the neuronal leptin and insulin signaling pathways [53] and is associated with feeding behavior in pigs [54], and $A M E R 3$, which is involved in embryogenesis [55]. This $\mathrm{ROH}$ island on BBU2 also harbors the ARHGEF4 gene, which is associated with milk production traits in dairy cattle [56] and the PLEKHB2 gene, which is associated with residual feed intake in beef cattle [57]. Both the AMER3 and PLEKHB2 genes have been reported to be located in a $\mathrm{ROH}$ island on chromosome 18 in the Lipizzan horse [58].

No candidate genes were found in the other $\mathrm{ROH}$ islands detected in the ALL_DATA set.

\section{RIVER_DATA set}

The largest $\mathrm{ROH}$ island in the RIVER_DATA set (about $10.8 \mathrm{Mb}$ and 109 SNPs) was detected on BBU3 (see Additional file 10: Table S4). We identified three genes related to environmental adaptation and body development, i.e., $H L F, M M D$, and STXBP4, in this region (see Additional file 11: Table S5). These genes have also been found in a $\mathrm{ROH}$ island located on horse chromosome 11 [59]. The second largest $\mathrm{ROH}$ island in river buffalo is located on BBU1. It contains genes that are associated with muscle contraction (MYOM2) [60], iron content (RCAN1) [61], and fatty acid metabolism (ARHGEF10) [62]. Further interesting genes that map in this $\mathrm{ROH}$ island are $A R H$ GEF10, CLN8 and DGAP2, that were associated with hairless phenotype in pigs [63]. This $\mathrm{ROH}$ island also contains a group of genes that are involved in polledness in cattle [64, 65] and yak [66]: IFNGR2, IFNAR1, and SYNJ1.

Several other interesting genes were identified within the $\mathrm{ROH}$ islands detected in river buffaloes: LGR5 on BBU4, previously proposed as a candidate gene for supernumerary teats in cattle [67]; $U B E 2 H$ on BBU8 that is associated with feed efficiency in cattle [68]; two genes on BBU9: PCDHB7, which has been suggested as a candidate gene for milk protein composition [69], and CD14, which is involved in the immune response of the cattle mammary tissue infected by Streptococcus agalactiae [70]; and CDK10 on BBU18 at 14-14.6 Mb, which has been reported to be present in a selection signature in African local cattle breeds [71].

\section{Principal component analysis of swamp and river $\mathrm{G}_{\mathrm{ROH}}$ matrices}

The first two eigenvectors of the $\mathbf{G}_{\mathrm{ROH}}$ calculated by using the SNPs of the ALL_DATA set, explained 4 and $1 \%$ of the total variance, respectively. The plot of eigenvector coefficients (Fig. 6) shows a clear distinction between the two buffalo types. The first eigenvector separates river and swamp buffaloes, and the second one shows a withintype gradient. The differences between populations and breed are better illustrated on the principal component analysis that was carried out on the $\mathbf{G}_{\mathbf{R O H}}$ derived from the RIVER_DATA and SWAMP_DATA sets, respectively. Moreover, the patterns are easier to detect if the population means of eigenvectors are plotted, instead of the coefficients for each single animal (Figs. 7a, b, 8a, b). In this case, swamp buffalo populations display a geographical North-South cline along the second eigenvector (Fig. 7a), with the Indonesian populations clustered at the top left, with the exception of the Sumatran population which is in an intermediate position, and the Chinese populations at the bottom right of the plot, respectively. The first eigenvector clusters the Chinese populations and separates them from Indonesian and Thailand buffaloes. The third eigenvector (Fig. 7b) emphasizes the distance between swamp buffaloes from the Philippines and, the Indonesian populations.

The pattern among river buffalo breeds is less welldefined, but it also follows partly a geographical

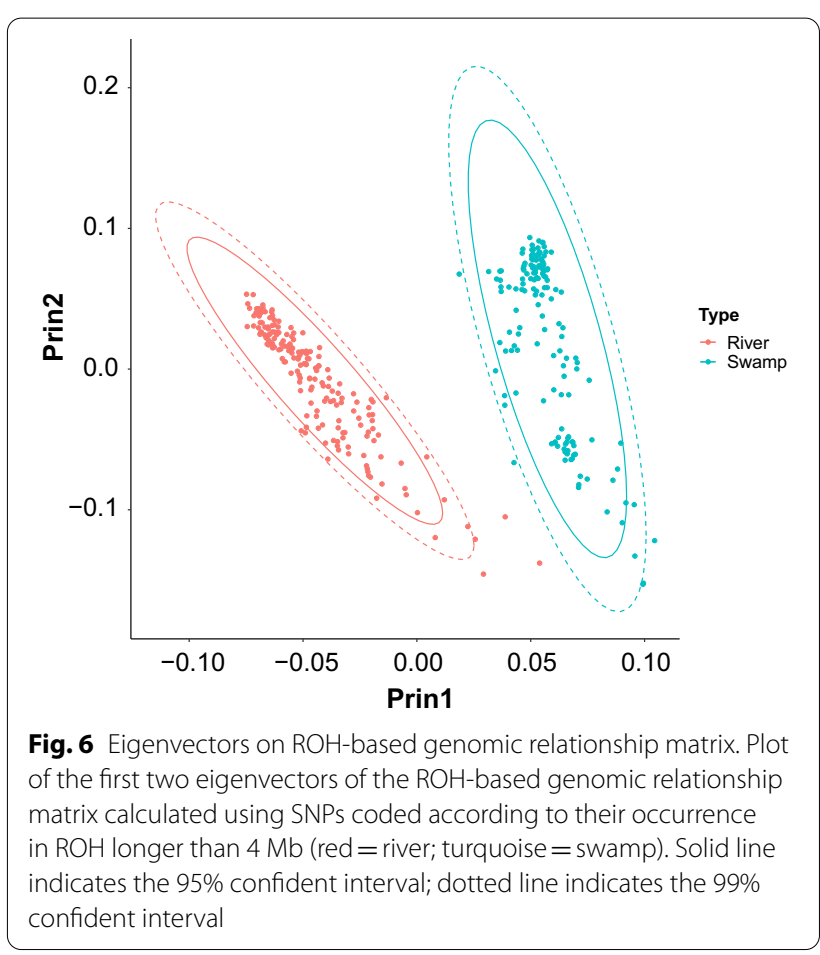




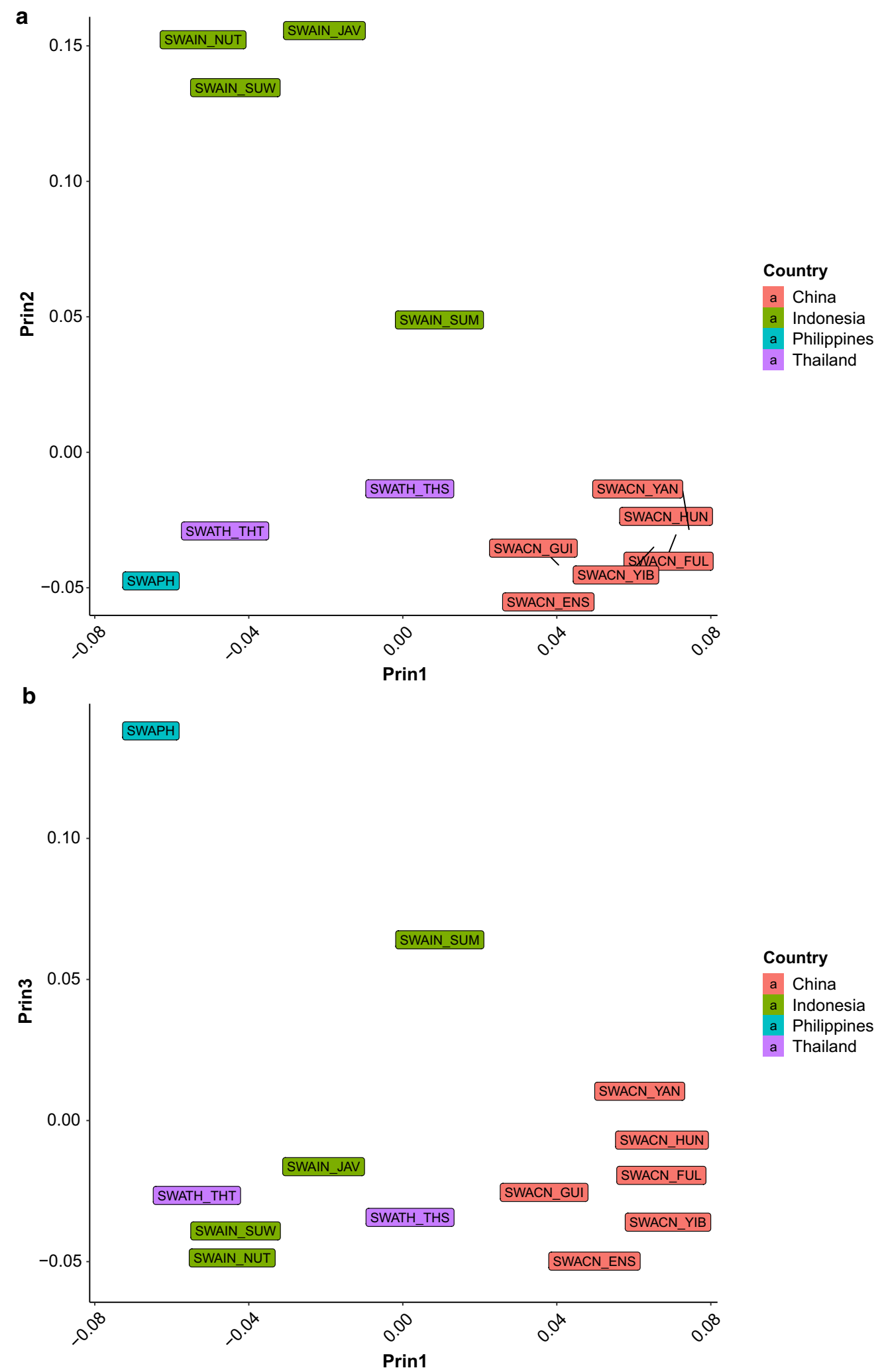

Fig. 7 Eigenvectors on $\mathrm{ROH}$-based genomic relationship matrix in swamp buffaloes. Plot of the swamp buffalo population means of the first two (a), and the third and second (b) eigenvectors of the ROH-based genomic relationship matrix calculated using ROH longer than $4 \mathrm{Mb}$. Different colors indicate different countries of origin 
a

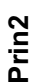

RIVMZ $0^{5}$

b

Prin1

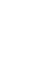
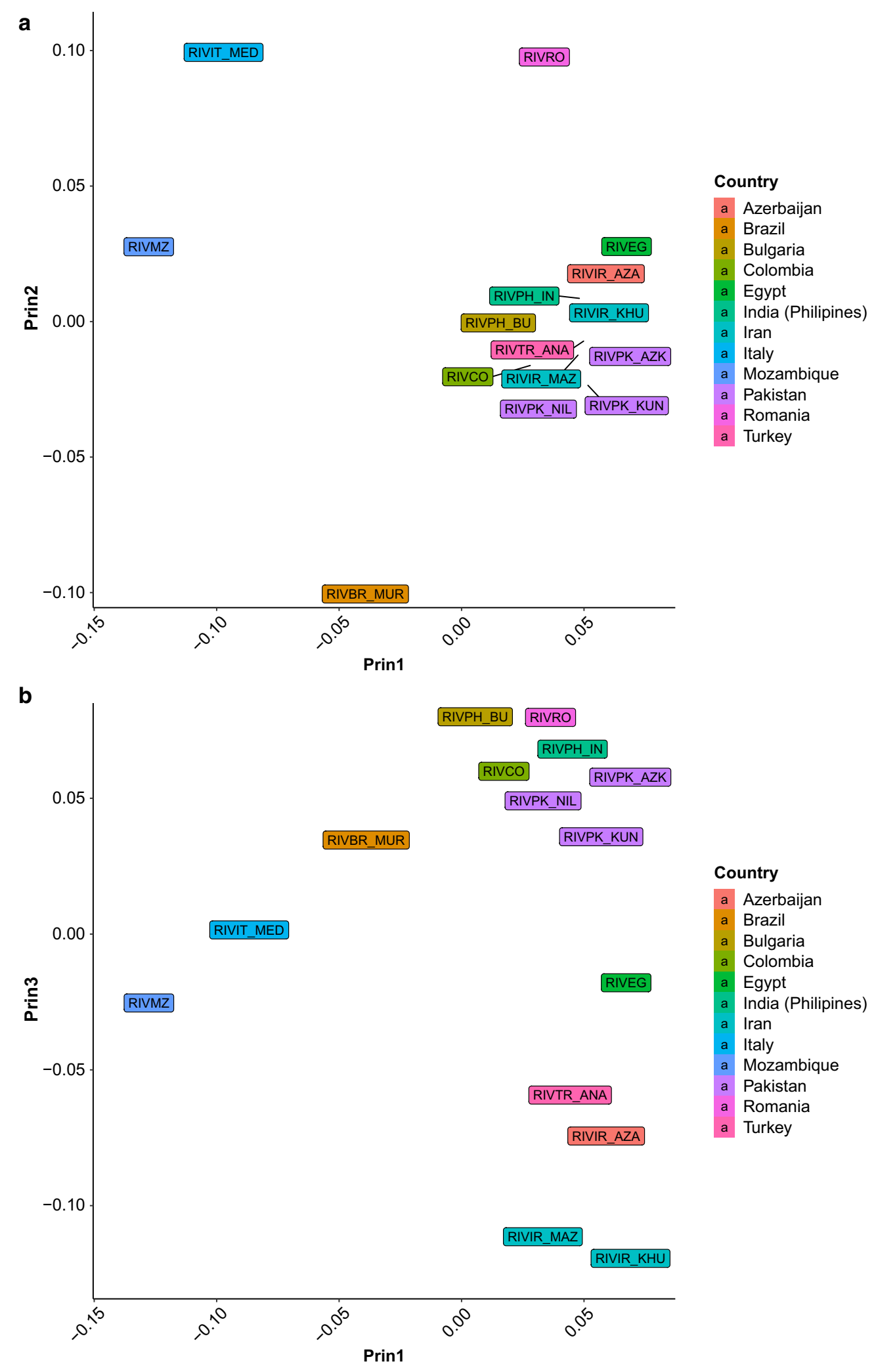

RIVRO

Country

Azerbaijan

Brazil

Bulgaria

Colombia

Egypt

India (Philipines)

Iran

Italy

Mozambique

Pakistan

Romania

Turkey
Fig. 8 Eigenvectors on ROH-based genomic relationship matrix in river buffaloes. Plot of the river buffalo population means of the first two (a), and the third and second (b) eigenvectors of the $\mathrm{ROH}$-based genomic relationship matrix calculated using $\mathrm{ROH}$ longer than $4 \mathrm{Mb}$. Different colors indicate different countries of origin 
distribution, with an East-West orientation of the first eigenvector (Fig. 8a) that clusters the breeds of the eastern and middle east countries on the right side of the plot, and the two Mediterranean breeds, Italian and Mozambique, in the top left, respectively. The second eigenvector distinguishes the Mediterranean and Iranian breeds. Of interest, the third eigenvector (Fig. 8b) shows a separation between breeds from Pakistan, Egypt, Turkey, and Iran.

\section{Discussion}

\section{ROH distribution}

Analysis of $\mathrm{ROH}$ distributions in river and swamp buffaloes, and between populations/breeds provide interesting insights into their genetic structure. $\mathrm{ROH}$ were detected in both buffalo types and in all breeds/populations. The number of $\mathrm{ROH}$ was larger in swamp (>43\%) than in river buffaloes when they were analyzed jointly using the same set of SNPs. The average $\mathrm{ROH}$ frequency per animal detected in the two buffalo types (40 in the river and 77 in the swamp, respectively) is comparable with figures that have been previously reported for buffalo, e.g., AzaKheli and Khuzestani Iranian river buffalo breeds that have an average n_ROH of 21 and 33, respectively [24]. The average $\mathrm{ROH}$ frequency per animal in other livestock species ranges from 24 to 77 in sheep and goats [72-74], from 40 to 90 in Bos taurus cattle [21, 27, 75] and 55 in Bos indicus cattle [76]. However, the number of $\mathrm{ROH}$ detected depends on the density of the SNP panel, the informativeness and size of the sample, and on the algorithms and $\mathrm{ROH}$ parameters used for $\mathrm{ROH}$ identification. This is confirmed by our results, which show that different numbers of $\mathrm{ROH}$ were detected for the same populations depending on the ALL_DATA or RIVER_DATA set used, which differ in the number of SNPs.

The occurrence of $\mathrm{ROH}$ in a population mirrors its genetic and demographic history. The present study highlighted a difference in $\mathrm{ROH}$ number between river and swamp buffaloes, especially for the shortest $\mathrm{ROH}$ (<4 Mb) (Fig. 1). Swamp buffalo individuals showed both a larger number of homozygous segments and a larger $\mathrm{ROH}$ coverage of the genome compared to river buffaloes. The conclusions based on descriptive statistics are supported by the results of the logistic regression analysis that highlighted a significantly higher probability of a SNP to be included in a $\mathrm{ROH}$ in swamp than in river buffalo. The effect of ascertainment bias of the SNP array was, at least in part, addressed by using the $17.8 \mathrm{~K}$ SNPs that were polymorphic in swamp buffalo. This reduced set of SNPs showed substantial concordance of results with the RIVER_DATA set that included 46 K SNPs, which suggests that the lower density SNP panel was sufficient to identify coarse features of the buffalo genome structure. In a previous study, a subset of $20 \mathrm{~K}$ SNPs from the same beadchip used in this study has been used to differentiate swamp buffalo from river buffalo [77]. As a general consideration, it should be pointed out that short $\mathrm{ROH}$ are more likely to be false positives than long $\mathrm{ROH}$. Some authors pointed out that the use of $50 \mathrm{~K}$ SNP panels may overestimate the number of $\mathrm{ROH}$ shorter than $5 \mathrm{Mb}$ because of the long gap between homozygous SNPs $[75,78]$. In our paper, the average distance between SNPs in the shortest $\mathrm{ROH}$ class was similar for both buffalo types, $90 \mathrm{~kb}$ (1-2 Mb class) and $135 \mathrm{~kb}$ (2-4 Mb class), respectively. When the $\mathrm{ROH}$ shorter than $4 \mathrm{Mb}$ were discarded, the pattern of $\mathrm{ROH}$ and $\mathrm{ROH}$ genome coverage remained essentially unchanged (see Additional file 12: Figure S7, Additional file 13: Figure S8), with most of the river buffalo individuals showing a smaller number and a reduced $\mathrm{ROH}$ genome coverage compared to the swamp buffalo individuals.

The observed higher frequency of short $\mathrm{ROH}$ in swamp buffalo individuals is likely to be related to their genetic history, in particular to the lack of strong anthropogenic selection and to geographic differentiation [77]. The river buffalo type has been subjected to more intense selection than the swamp type, especially for dairy traits $[7,10,15]$. In our study, the average $\mathrm{ROH}$ length was longer in river buffalo when the two buffalo types were analyzed using the same set of SNPs. This difference was confirmed by the generalized mixed model analysis that also identified differences between breeds or populations, showing a significant within-type heterogeneity. Variation in $\mathrm{ROH}$ length as a result of different selection pressures has been reported in cattle, in which it has contributed to the maintenance of long homozygous tracts [19]. A higher frequency of short $\mathrm{ROH}(<4 \mathrm{Mb})$ has been reported in beef compared to dairy cattle [27], which was attributed to the more intense selection in dairy breeds. A worldwide analysis of homozygosity patterns in goats reported a larger proportion of the genome covered by $\mathrm{ROH}$ in populations farmed on islands, due to the geographical isolation, and for local breeds, compared to globally used breeds [68]. A relationship between length of homozygous segments and geographical differentiation has also been observed in humans, e.g., an excess of shorter $\mathrm{ROH}$ was found in populations from the Pacific Ocean islands [18]. The small population sizes and geographical isolation on these islands were proposed as possible explanations for these results.

\section{Dissection of the $\mathrm{G}_{\mathrm{ROH}}$}

Genetic stratification of populations can be detected from eigenvalue analysis of genomic relationship matrices. The eigenvalue analysis of the standard SNP-based genomic matrix (G) for domestic water buffalo showed 
a clear separation between swamp and river buffalo types [7]. A ROH-derived genomic matrix may capture different aspects of the relationships between individuals, based on the sharing of homozygous segments. Luan et al. [20] developed an identical-by-descent (IBD) $\mathbf{G}_{\mathbf{R O H}}$ for genomic prediction purposes based on the coalescence theory and was able to account for mutation and recombination [79]. In our paper, a method for constructing an identical-by-state (IBS) $\mathbf{G}_{\mathbf{R O H}}$ based on the recoding of SNP genotypes according to their location within a $\mathrm{ROH}$ is proposed. This method estimates a matrix that could be calculated following the method of [31]. The separation between types and breeds using the eigenvalue decomposition of the $\mathbf{G}_{\mathbf{R O H}}$ matrix that is calculated by using $\mathrm{ROH}$ longer than $4 \mathrm{Mb}$ (Fig. 6) gives a pattern similar to that obtained from a standard genomic relationship matrix using individual SNPs (see [7]), including the North-South cline exhibited by swamp buffalo populations (Fig. 7a). Geographical differentiation of many populations based on $\mathrm{ROH}$ analyses has been reported for a very wide range of mammalian species $[23,28,80]$, especially when unselected or local populations were investigated. The clustering of the Chinese swamp buffalo populations and their distance from Indonesian and Philippine individuals confirms previous reports based on the analysis of microsatellite loci [81] that indicated a low degree of genetic differentiation in Chinese swamp buffaloes compared to south-east Asian animals. The large distance between Indonesian buffaloes and the other populations (Fig. 7a) may be explained by the effect of geographical isolation and genetic drift. The intermediate position of the swamp buffalo population from Sumatra agrees with the results of [7] who reported that only $30 \%$ of the genome was shared between Sumatra and the other Indonesian populations. The clear separation between swamp buffaloes from the Philippines and the other swamp buffalo populations based on the third principal component of the $\mathbf{G}_{\text {ROH }}$ (Fig. 7b) can be explained by the introgression of river buffalo gene pools through crossbreeding that is used to improve milk production [7]. Such crossbreeding between the two buffalo types in the Philippines was initiated nearly 50 years ago [82] and introgression of river buffalo genes into the genome of swamp buffaloes is currently increasing.

The distribution of river buffalo breeds does not follow a strict geographical pattern. Figure 8a, b show that Iranian, Turkish, and Egyptian river buffaloes cluster together, in agreement with their geographical proximity, whereas breeds from Italy, Mozambique, and, to a lesser extent, Romania, and Brazil are separated from the other groups. This can be explained by the population histories, i.e., river buffaloes from Italy have been exported to Mozambique, Brazil [82] and Romania, and hence these populations share a common "Mediterranean" genomic background. Murrah buffaloes from India have also been imported into Brazil [82, 83]. Of interest is the relative proximity between the Romanian river buffalo and the Bulgarian Murrah river buffalo (Fig. 8b). The Bulgarian breed originated from crosses between indigenous Mediterranean animals and imported Indian Murrah buffaloes [7]. Additional crosses with Romanian river buffaloes have also been reported [84]. Thus, the first principal component of the $\mathbf{G}_{\mathbf{R O H}}$ of the river buffalo breeds could be interpreted as an index of the "Mediterranean" content of the genome, whereas the second dimension is an index of the transition between Mediterranean and Murrah buffalo genomes.

\section{ROH-based inbreeding}

Traditionally, estimation of inbreeding has been based on pedigree data, which often underestimated the true level of inbreeding because, usually, pedigree data are only available for a few generations [85]. Calculation based on SNP data is more accurate and it enables genomic relationships to be estimated even when pedigree records are not available or incomplete, as in the case of buffaloes. In the present work, values of $\mathrm{F}_{\mathrm{ROH}}$ varied greatly between populations, especially for the swamp buffaloes, and depended on the minimum length of the $\mathrm{ROH}$ considered in the calculation. Higher inbreeding coefficients were obtained using all the $\mathrm{ROH}$ in the calculation. Mean values of $\mathrm{F}_{\mathrm{ROH}}$ calculated in the present study for Brazilian Murrah, Aza-Kheli and Khuzestani breeds (Fig. 4a) are close to those reported in literature for these three breeds (i.e., 2\%) by [25].

The use of longer $\mathrm{ROH}\left(>4 \mathrm{Mb}\right.$ ) gave an average $\mathrm{F}_{\mathrm{ROH}}$ of 3 to $4 \%$ for both types. Iranian and Chinese breeds had the lowest values and the least variability in $\mathrm{F}_{\mathrm{ROH}}$ for the river and swamp buffalo types, respectively. The $\mathrm{F}_{\mathrm{ROH}}$ variability could be due to differences in genetic history, breeding management, and/or sampling effect among populations. For example, river buffaloes sampled in Mozambique, that exhibited a large $F_{\mathrm{ROH}}$ variability (Fig. 4), derive from a well-known exportation of Mediterranean buffaloes from central Italy in 1969 [82]. Likely due to a founder effect and the subsequent prolonged isolation, the current population of river buffaloes from Mozambique displays the lowest values for both observed and expected heterozygosity values among all river buffalo populations [7], which is likely due to a founder effect and subsequent prolonged isolation. Genomic inbreeding coefficients obtained in our study using $\mathrm{ROH}$ longer than $4 \mathrm{Mb}$ are generally slightly higher than pedigree-based values reported in the literature. Values between 1.2 and 2.4\% were reported for Brazilian Murrah and Mediterranean buffaloes farmed in Brazil 
[83, 84], respectively. Inbreeding coefficients of 2.4 and $3.42 \%$ have been reported for buffalo populations from the Mediterranean area [85] and Iranian buffaloes [86], respectively.

A higher inbreeding level is expected for more intensely selected animals, i.e., from the river buffalo type. However, we observed a substantial similarity between the two buffalo types in the ALL_DATA set, except when all $\mathrm{ROH}$ were considered (Table 3 ). The higher $\mathrm{F}_{\mathrm{ROH}}$ observed for swamp buffaloes in this case was basically due to a larger n_ROH, and particularly of short length $(<4 \mathrm{Mb})$ (Table 2; Fig. 1). Such a difference between the two buffalo types could have biased downwards the inbreeding estimation in river buffaloes. However, the results of the analysis carried out on the RIVER_DATA set with many more SNPs (about 2.5 times more) showed that, in spite of a larger number of $\mathrm{ROH}$ per individual (107 vs 40), the $\mathrm{F}_{\mathrm{ROH}}$ values for river buffalo were quite close to those obtained with the ALL_DATA set. The effect of this more intense selection in river buffalo on $\mathrm{ROH}$ features is essentially observed for $\mathrm{ROH}$ length, which is longer for river than swamp buffaloes, and not for the $\mathrm{ROH}$ based genomic inbreeding. Such a moderate effect on the structure of the river buffalo genome should be ascribed to the lower selection pressure that this species has been subjected to in comparison with specialized dairy cattle breeds. Zhang et al. [87] pointed out that organized buffalo breeding programs that use artificial insemination still need to be developed in many countries.

\section{ROH islands}

Genomic regions characterized by a high level of homozygosity have been detected in many livestock species $[24,28,58,72,74,76]$. $\mathrm{ROH}$ occurrence may be the result of common ancestry, selection pressure, chromosome structure, and linkage disequilibrium [78]. In our work, we detected $\mathrm{ROH}$ that were shared among different buffalo populations. In particular, 10 unique $\mathrm{ROH}$ that started and finished at exactly the same positions, were found in six or more individuals from different populations. A ROH on BBU16 occurred in six river buffaloes of breeds from Italy and Mozambique, which are known to be genetically related. In cattle, shared $\mathrm{ROH}$ have been detected in local breeds from the two main Italian islands, Sicily and Sardinia [28]. The same ROH were found in genetically related populations, but not in a cosmopolitan breed [28]. Some of the ROH detected in our study were present in both swamp and river buffaloes. Crossbreeding between the two buffalo types to improve swamp buffalo productivity has been a common practice in several east Asian countries [7, 12] and in central America [88]. Transfer and ongoing selection on genomic regions associated with productivity may, in part, explain these shared $\mathrm{ROH}$.

The use of unique $\mathrm{ROH}$ to study the genomic similarity between individuals is restrictive when they share the core of a region of homozygosity that does not start or finish exactly at the same position. Since a $\mathrm{ROH}$ roughly reflects an IBS haplotype, the precise location of the beginning and end of a $\mathrm{ROH}$ may not be important. The use of $\mathrm{ROH}$ islands in our study (i.e., a stretch of consecutive SNPs where $\mathrm{SNP}_{\mathrm{ROH}}$ exceed a certain threshold) is a more flexible way of comparing homozygous regions between individuals. The largest $\mathrm{ROH}$ island detected in the two buffalo types, using the three datasets, was located on BBU2, between 47 and $58 \mathrm{Mb}$. A $\mathrm{ROH}$ island located on BBU2 between 52.8 and $53.8 \mathrm{Mb}$ was recently reported in Murrah buffaloes [25]. A ROH hotspot has also been detected at the corresponding position on bovine chromosome 2 [21], which is the homolog of BBU2 [11]. Moreover, $\mathrm{ROH}$ islands on chromosome 2 at 68.7, 71.3, and $81.9 \mathrm{Mb}$ have been reported in Bos indicus [76]. These $\mathrm{ROH}$ harbor genes that are related to dairy traits. A ROH island on Ovis aries chromosome OAR2 has been detected in three sheep breeds (Belclare, Suffolk and Texel) [29]. This ROH overlaps the myostatin (MSTN) gene, which is involved in muscle development and most likely is under selection. A possible interpretation for the occurrence of the same $\mathrm{ROH}$ island in different species could be due to evolutionary convergence caused by the selection on the same group of genes. It is noteworthy that two of the genes present in the $\mathrm{ROH}$ island on BBU2 (ARHGEF4 and PLEKHB2) which are associated with milk yield and feed efficiency in ruminants, are also present in a $\mathrm{ROH}$ hotspot on chromosome 18 of the horse. Although shorter $\mathrm{ROH}$ islands represent a weak signal that needs to be carefully validated with other studies and approaches, the consistency between the results on the $\mathrm{ROH}$ located on BBU2 with the three datasets of the present study and those from other studies on buffalo and other species suggests that the $\mathrm{ROH}$ approach is useful to study the major features of genomes.

Short $\mathrm{ROH}$ are ancient and may derive from environmental adaptation, whereas longer $\mathrm{ROH}$ are more recent and are more likely to result from artificial selection or population bottleneck events. We found that $\mathrm{ROH}$ were longer in river than swamp buffalo breeds, which reflects the different histories and usages of each buffalo type worldwide. In fact, river buffaloes are subdivided in a number of well-recognizable breeds, based on geographical location and morphological traits (e.g., Murrah, Nili-Ravi, Kundi, Jafarabadi and Nagpuri in 
India and Pakistan, or the Mediterranean buffalo breed group spread in Italy, Bulgaria, Romania, Greece, Turkey, Egypt, Iran, Iraq, and Syria). They are mainly farmed and selected for milk production, and secondarily for meat. Conversely, swamp buffaloes are phenotypically homogeneous throughout their distribution area and no breeds are formally recognized. Swamp buffaloes, which are farmed primarily as draught animals for ploughing and transport, are not subjected to intense human-mediated selective pressures and also provide meat as a secondary product.

A few genes related to production traits were located in the $\mathrm{ROH}$ islands detected on the buffalo genome. $A R H$ GEF4, which is known to be associated to dairy traits, was detected in the $\mathrm{ROH}$ on BBU2 that is shared between both buffalo types. All the other genes related to production traits were identified in the analyses of the RIVER DATA set but not of the SWAMP_DATA set: e.g., $P C D H B 7$ and $U B E 2 H$, which are related to dairy traits, and TRNAG, MYOM2, AADAT, and RCAN1, which are related to beef traits. $M Y O M 2$ is present in a signature of selection that was identified in a comparison between Atzeri and Khuzestani Iranian buffaloes using $\mathrm{F}_{\mathrm{ST}}$ metrics [16]. The small number of genes related to dairy traits that was retrieved in the detected selection sweeps confirms the low selection pressure for milk production in buffalo in comparison, for example, with cattle.

Our results suggest that the main driving force in shaping the genome of the domestic water buffalo is adaptation to the environment. This is supported by most of the genes that map to the $\mathrm{ROH}$ islands detected in the ALL_DATA set and that are related to fitness traits. In particular, the largest group consists of genes that are associated with reproduction traits in livestock: male fertility ( $A D A M 32, I Q C G$, and $D S T$ ), female fertility (ADAM9, ADCY2, KALRN, RAB23, KHDRBS2, and TUBGCP5) and embryogenesis (ANXA10, PLEKHA2, FGFR1, and $A M E R 3)$. The second largest group of genes identified in $\mathrm{ROH}$ are involved in disease resistance such as KALRN, ITGB5, MUC13, HEG1, and LHCR3 in the ALL_DATA set, and HLF, MMD, SH3RF1, STXBP4, CD14, and CDK10, in the RIVER_DATA set.

Surviving and producing in arid areas represents a strong environmental challenge for livestock. The buffalo is a species that has a reduced tolerance to heat stress due to the poor distribution of its sweat glands, its very short and sparse hairs, and the dark color of its body [89]. However, in many countries, buffaloes are exposed to extreme heat stress, for example, in Iran [16]. Wallowing in mud and water protects them from solar irradiation and provides a cooling effect; it is a learnt adaptive behavior that buffaloes use to adapt to tropical and subtropical climates [90]. However, natural selection for resistance to heat stress may have occurred in some breeds [24]. The genes identified in the $\mathrm{ROH}$ islands in our study included some genes that have been implicated in the mechanisms of tolerance to hot and humid climates, such as those associated with skin pigmentation and eye disorders (LGSN, OCA2, and HERC2), and breathing rate (LIMS2). Another interesting group of genes that were identified within $\mathrm{ROH}$ is associated with the hairless phenotype (ARHGEF10, CLN8, and DGAP2) [62]. Finally, further evidence of environmental adaptation is suggested by the detection in $\mathrm{ROH}$ of genes related to feed efficiency (UMPS, TPN18, and PLEKHB2). The efficiency of the process of digestion is extremely important for surviving in extreme arid areas [91]. Our results agree with previous reports on indicine cattle, which highlighted $\mathrm{ROH}$ hotspots that harbor genes involved in the mechanism of adaptation [92].

Selection footprints identified from $\mathrm{ROH}$ analyses should be corroborated by other well-proven techniques. Although one should keep in mind that most metrics are based on comparisons between breeds or populations, whereas the rationale behind the search for selection sweeps using $\mathrm{ROH}$ is the sharing of homozygous regions by a large number of animals. In our paper, $\mathrm{F}_{\mathrm{ST}}$ values were calculated for the ALL_DATA set. Some SNPs that distinguished the two buffalo types also frequently occurred in homozygous regions. Moreover, average $\mathrm{F}_{\mathrm{ST}}$ values of SNPs included in the $\mathrm{ROH}$ islands were larger than the average values for the corresponding chromosome. These results further confirm that different metrics, although calculated from the same data, can offer complementary perspectives to analyze genome features and we recommend their combined use.

\section{Conclusions}

In the present study, runs of homozygosity were used to investigate the genomic structure of the two buffalo types and their breeds, and to compare populations of domestic water buffalo. In particular, the dissection of the $\mathrm{ROH}$ based genomic relationship matrix suggested that the two buffalo types have undergone environmental adaptation. The geographical isolation of populations together with genetic drift, have played a substantial role in shaping the genome of buffalos, especially of the swamp type. Analysis of the distribution of $\mathrm{ROH}$ islands on BBU2 identified a region that is shared with other ruminant species. The evolutionary significance of this region merits further investigation. 


\section{Supplementary Information}

The online version contains supplementary material available at https://doi. org/10.1186/s12711-021-00616-3.

\author{
Additional file 1: Table S1. Minor allele frequency in river and swamp \\ buffalos.
}

Additional file 2: Figure S1. Plot of linkage disequilibrium $\left(r^{2}\right)$ according to the distance between markers in river and swamp.

Additional file 3: Figure S2. Frequency distribution of $\mathrm{ROH}$ across chromosomes in river (black bars) and swamp (white bars) buffalo

Additional file 4: Figure S3. Distribution of the average ROH length per chromosome in river (white bars) and swamp (black bars) buffalo populations.

Additional file 5: Table S2. Top ten most frequently detected $\mathrm{ROH}$ in the ALL_DATA set.

Additional file 6: Figure S4. Stacked bar graph of $\mathrm{ROH}$ distribution on BBU4 in river (a) and swamp (b) buffalo.

Additional file 7: Figure S5. Stacked bar graph of ROH distribution on BBU17 in river (a) and swamp (b) buffalo.

Additional file 8: Figure S6. Manhattan plot of smoothed $F_{\text {ST }}$ values for chromosomes 1 to 24

Additional file 9: Table S3. Top five most frequently detected $\mathrm{ROH}$ in RIVER_DATA and SWAMP_DATA sets.

Additional file 10: Table S4. Chromosomal location of significant SNPS (i.e. with $\mathrm{SNP}_{\mathrm{ROO}}$ values located in the top 1\%) in the RIVER_DATA and SWAMP_DATA sets.

Additional file 11: Table S5. Genes mapped in the ROH islands highlighted in this study [93-112].

Additional file 12: Figure S7. Relationship between number of $\mathrm{ROH}$ and total length of the genome covered by ROH (using all ROH detected in ALL_DATA set).

Additional file 13: Figure S8. Relationship between number of $\mathrm{ROH}$ and total length of the genome covered by $\mathrm{ROH}$ (using $\mathrm{ROH}$ with length $\geq 4 \mathrm{Mb}$ detected in the ALL_DATA set).

\section{Acknowledgements}

The authors are grateful to all members of the International Buffalo Consortium for the provision of data used in this study.

\section{Authors' contributions}

NM conceived the work and wrote the first version of the manuscript; AC and NM performed data analysis. WL and RT performed bioinformatic analysis and SNP alignment to buffalo genome assembly. AC, JLW, LC and PAM contributed to the interpretation of results. AC, LC, JLW and WL contributed in writing the paper. All authors read and approved the final manuscript.

\section{Funding}

Not applicable.

\section{Availability of data and materials}

SNPs genotype data used in this study are available at the Dryad repository (https://doi.org/10.5061/dryad.h0cc7).

\section{Ethics approval and consent to participate}

Animal Care and Use Committee approval was not needed as data were obtained from preexisting databases.

\section{Consent for publication}

The authors read and approved this version of the manuscript and they declare their consent for publication.

\section{Competing interests}

The authors declare that they have no competing interests.

\section{Author details}

1 Dipartimento di Agraria, Università degli Studi di Sassari, Sassari, Italia.

${ }^{2}$ Dipartimento di Scienze Animali, della Nutrizione e degli Alimenti-DIANA, Università Cattolica del Sacro Cuore, Piacenza, Italia. ${ }^{3}$ Centro di Ricerca sulla Biodiversità e sul DNA Antico-BioDNA, Università Cattolica del Sacro Cuore, Piacenza, Italia. ${ }^{4}$ Department of Animal and Dairy Science, University of Georgia, Athens, GA, USA. ${ }^{5}$ Centro di Ricerca Nutrigenomica e Proteomica-PRONUTRIGEN, Università Cattolica del Sacro Cuore, Piacenza, Italia. ${ }^{6}$ The Davies Research Centre, School of Animal and Veterinary Sciences, University of Adelaide, Roseworthy, SA 5371, Australia.

Received: 29 September 2020 Accepted: 17 February 2021

Published online: 27 February 2021

\section{References}

1. Gu M, Cosenza G, lannaccone M, Macciotta NPP, Guo Y, Di Stasio L, et al. The single nucleotide polymorphism g.133A $>C$ in the stearoyl CoA desaturase gene (SCD) promoter affects gene expression and quali-quantitative properties of river buffalo milk. J Dairy Sci. 2019;102:442-51.

2. da Costa Barros C, de Abreu Santos DJ, Aspilcueta-Borquis RR, Ferreira de Camargo GM, de Araújo Neto FR, Tonhati H. Use of single-step genome-wide association studies for prospecting genomic regions related to milk production and milk quality of buffalo. J Dairy Res. 2018;85:402-6.

3. FAOSTAT, 2019. http://www.fao.org/faostat/en/\#home. Accessed $10 \mathrm{Apr}$ 2020

4. Di Berardino D, lannuzzi L. Chromosome banding homologies in Swamp and Murrah buffalo. J Hered. 1981;72:183-8.

5. Degrandi TM, Pita SB, Panzera Y, de Oliveira EHC, Marques JRF, Figueiró MR, et al. Karyotypic evolution of ribosomal sites in buffalo subspecies and their crossbreed. Genet Mol Biol. 2014;37:375-80.

6. Iannuzzi L, Di Meo GP. Water buffalo. In: Cockett NE, Kole C, editors. Genome mapping and genomics in domestic animals. Berlin: Springer; 2009. p. 19-31.

7. Colli L, Milanesi M, Vajana E, lamartino D, Bomba L, Puglisi F, et al. New insights on Water Buffalo genomic diversity and post-domestication migration routes from medium density SNP chip data. Front Genet. 2018:9:53.

8. Zhang Y, Lu Y, Yindee M, Li KY, Kuo HY, Ju YT, et al. Strong and stable geographic differentiation of swamp buffalo maternal and paternal lineages indicates domestication in the China/Indochina border region. Mol Ecol. 2016;25:1530-50.

9. Wang S, Chen N, Capodiferro MR, Zhang T, Lancioni $\mathrm{H}$, Zhang H, et al. Whole mitogenomes reveal the history of swamp buffalo: initially shaped by glacial periods and eventually modelled by domestication. Sci Rep. 2017;7:4708.

10. Williams J L, lamartino D, Pruitt KD, Sonstegard T, Smith TPL, Low WY, et al. Genome assembly and transcriptome resource for river buffalo, Bubalus bubalis $(2 \mathrm{n}=50)$. GigaScience. 2017;6:gix088.

11. Low WY, Tearle R, Bickhart DM, Rosen BD, Kingan B, Swale T, et al. Chromosome-level assembly of the water buffalo genome surpasses human and goat genomes in sequence contiguity. Nat Commun. 2019;10:260.

12. lamartino D, Nicolazzi EL, Van Tassell CP, Reecy JM, Fritz-Waters ER, Koltes JE, et al. Design and validation of a 90K SNP genotyping assay for the water buffalo (Bubalus bubalis). PLoS One. 2017;9:e0185220.

13. de Camargo GMF, Aspilcueta-Borquis RR, Fortes MRS, Porto-Neto R, Cardoso DF, Santos DJA, et al. Prospecting major genes in dairy buffaloes. BMC Genomics. 2015;16:872.

14. El-Halawany N, Abdel-Shafy H, Shawky AEMA, Abdel-Latif MA, AlTohamy AFM, El-Moneim OMA. Genome-wide association study for milk production in Egyptian buffalo. Livest Sci. 2017;198:10-6.

15. Liu JJ, Liang AX, Campanile G, Plastow G, Zhang C, Wang Z, et al. Genome-wide association studies to identify quantitative trait loci affecting milk production traits in water buffalo. J Dairy Sci. 2018;101:433-44.

16. Mokhber M, Moradi-Shahrbabak M, Sadeghi M, Moradi-Shahrbabak $H$, Stella A, Nicolazzi EL, et al. A genome-wide scan for signatures of 
selection in Azeri and Khuzestani buffalo breeds. BMC Genomics. 2018;19:449.

17. Broman KW, Weber JL. Long homozygous chromosomal segments in reference families from the Centre d'Etude du Polymorphisme Humain. Am J Hum Genet. 1999;65:1493-500.

18. Kirin M, McQuillan R, Franklin CS, Campbell H, McKeigue PM, Wilson JF. Genomic runs of homozygosity record population history and consanguinity. PLoS One. 2010;5:e13996.

19. Purfield DC, Berry DP, McParland S, Bradley DG. Runs of homozygosity and population history in cattle. BMC Genet. 2012;13:70.

20. Luan T, Yu X, Dolezal M, Bagnato A, Meuwissen THE. Genomic prediction based on runs of homozygosity. Genet Sel Evol. 2014;46:64.

21. Kim K, Jung J, Caetano-Anollés K, Sung S, Yoo D, Choi BH, et al. Artificial selection increased body weight but induced increase of runs of homozygosity in Hanwoo cattle. PLoS One. 2018;13:e0193701.

22. Lee KT, Chung WH, Lee SY, Choi JW, Kim J, Lim D, et al. Whole-genome resequencing of Hanwoo (Korean cattle) and insight into regions of homozygosity. BMC Genomics. 2013;14:519.

23. Nothangel M, LuTT, Kayser M, Krawczak M. Genomic and geographic distribution of SNP-defined runs of homozygosity in Europeans. Hum Mol Genet. 2010;19:2927-35.

24. Ghoreishifar SM, Moradi-Shahrbabak H, Fallahi MH, Moradi-Shahrbabak M, Abdollahi-Arpanahi R, Khansefid M. Genomic measures of inbreeding coefficients and genome-wide scan for runs of homozygosity islands in Iranian river buffalo. BMC Genet. 2020;21:16

25. Nascimento AV, Cardoso DF, Santos DJA, Romero ARS, Scalez DCB, Borquis RRA, et al. Inbreeding coefficients and runs of homozygosity islands in Brazilian water buffalo. J Dairy Sci. 2021;104:1917-27.

26. Marras G, Rossoni A, Schwarzenbacher H, Biffani S, Biscarini F, Nicolazzi EL. ZANARDI: an open source pipeline for multiple-species genomic analysis of SNP array data. Anim Genet. 2017:48:121.

27. Marras G, Gaspa G, Sorbolini S, Dimauro C, Ajmone-Marsan P, Valentini $A$, et al. Analysis of runs of homozygosity and their relationship with inbreeding in five cattle breeds farmed in Italy. Anim Genet. 2015:46:110-21.

28. Cesarani A, Sorbolini S, Criscione A, Bordonaro S, Pulina G, Battacone G, et al. Genome-wide variability and selection signatures in Italian island cattle breeds. Anim Genet. 2018;49:371-83.

29. Purfield DC, McParland S, Wall E, Berry DP. The distribution of runs of homozygosity and selection signatures in six commercial meat sheep breeds. PLoS One. 2017;12:e0176780.

30. McQuillan R, Leutenegger AL, Abdel-Rahman R, Franklin CS, Pericic M, Barac-Lauc $L$, et al. Runs of homozygosity in European populations. Am J Hum Genet. 2008;83:359-72.

31. VanRaden PM. Efficient methods to compute genomic predictions. J Dairy Sci. 2008;91:4414-23.

32. Weir BS. Genetic data analysis II: methods for discrete population genetic data. Sunderland: Sinauer Associates, Inc:; 1996.

33. Pintus E, Sorbolini S, Albera A, Gaspa G, Dimauro C, Steri R, et al. Use of locally weighted scatterplot smoothing (LOWESS) regression to study selection signatures in Piedmontese and Italian Brown cattle breeds. Anim Genet. 2014;45:1-11.

34. Kijas JW, Lenstra JA, Hayes B, Boitard S, Porto Neto LR, San Cristobal $M$, et al. Genome-wide analysis of the world's sheep breeds reveals high levels of historic mixture and strong recent selection. PLoS Biol. 2012;10:e1001258.

35. Cesarani A, Sechi T, Gaspa G, Usai MG, Sorbolini S, Macciotta NPP, et al. Investigation of genetic diversity and selection signatures between Sarda and Sardinian Ancestral black, two related sheep breeds with evident morphological differences. Small Ruminant Res. 2019;177:68-75.

36. Choi I, Woo JM, Hong S, Jung YK, Kim DH, Cho C. Identification and characterization of ADAM32 with testis-predominant gene expression. Gene. 2003;304:151-62.

37. Hatzirodos N, Irving-Rodgers HF, Hummitzsch K, Harland ML, Morris SE, Rodgers RJ. Transcriptome profiling of granulosa cells of bovine ovarian follicles during growth from small to large antral sizes. BMC Genomics. 2014;15:24.

38. Jonczyk AW, Piotrowska-Tomala KK, Kordowitzki P, Skarzynski DJ. Effects of prostaglandin F2a on angiogenic and steroidogenic pathways in the bovine corpus luteum may depend on its route of administration. J Dairy Sci. 2019;102:10573-86.
39. Stafuzza NB, de Oliveira Silva RM, de Oliveira FB, Masuda Y, Huang Y, Gray K, et al. A genome-wide single nucleotide polymorphism and copy number variation analysis for number of piglets born alive. BMC Genomics. 2019;20:321.

40. Yin H, Zhou C, Shi S, Fang L, Liu J, Sun D, et al. Weighted single-step genome-wide association study of semen traits in Holstein bulls of China. Front Genet. 2019;10:1053.

41. Abo-Ismail MK, Lansink N, Akanno E, Karisa BK, Crowley JJ, Moore SS, et al. Development and validation of a small SNP panel for feed efficiency in beef cattle. J Anim Sci. 2018;96:375-97.

42. Aslam MKM, Sharma VK, Pandey S, Kumaresan A, Srinivasan A, Datta TK, et al. Identification of biomarker candidates for fertility in spermatozoa of crossbred bulls through comparative proteomics. Theriogenology. 2018;119:43-51.

43. Cole JB, Wiggans GR, Ma L, Sonstegard TS, Lawlor TJ Jr, Crooker BA, et al. Genome-wide association analysis of thirty-one production, health, reproduction and body conformation traits in contemporary U.S. Holstein cows. BMC Genomics. 2011:12:408.

44. Xin WS, Zhang F, Yan GR, Xu WW, Xiao SJ, Zhang ZY, et al. A whole genome sequence association study for puberty in a large Duroc $x$ Erhualian F2 population. Anim Genet. 2018;49:29-35.

45. Dominguez D, Freese P, Alexis MS, Su A, Hochman M, Palden T, et al. Sequence, structure, and context preferences of human RNA binding proteins. Mol Cell. 2018;70:854-67e9.

46. Guo J, Tao H, Li P, Li L, Zhong T, Wang L, et al. Whole-genome sequencing reveals selection signatures associated with important traits in six goat breeds. Sci Rep. 2018;8:10405.

47. Reverter A, Porto-Neto LR, Fortes MRS, McCulloch R, Lyons RE, Moore $\mathrm{S}$, et al. Genomic analyses of tropical beef cattle fertility based on genotyping pools of Brahman cows with unknown pedigree. J Anim Sci. 2016;94:4096-108.

48. Litzky JF, Deyssenroth MA, Everson TM, Armstrong DA, Lambertini L, Chen J, et al. Placental imprinting variation associated with assisted reproductive technologies and subfertility. Epigenetics. 2017;12:653-61.

49. Barragan I, Marcos I, Borrego S, Antiñolo G. Mutation screening of three candidate genes, ELOVL5, SMAP1 and GLULD1 in autosomal recessive retinitis pigmentosa. Int J Mol Cell. 2005;16:1163-7.

50. Chen H, Hey J, Slatkin M. A hidden Markov model for investigating recent positive selection through haplotype structure. Theor Popul Biol. 2015;99:18-30.

51. Fritz KL, Kaese HJ, Valberg SJ, Hendrickson JA, Rendahl AK, Bellone RR, et al. Genetic risk factors for insidious equine recurrent uveitis in Appaloosa horses. Anim Genet. 2014;45:392-9.

52. Jonnalagadda M, Ashhad Faizan M, Ozarkar S, Ashma R, Kulkarni S, Norton $\mathrm{HL}$, et al. A genome-wide association study of skin and iris pigmentation among individuals of South Asian ancestry. Genome Biol Evol. 2019:1:1066-76.

53. Tsou R, Bence K. Central regulation of metabolism by protein tyrosine phosphatases. Front Neurosci. 2013;6:192.

54. Do DN, Strathe AB, Ostersen T, Jensen J, Mark T, Kadarmideen HN. Genome-wide association study reveals genetic architecture of eating behavior in pigs and its implications for human obesity by comparative mapping. PLoS One. 2013;8:e71509.

55. Boutet A, Comai G, Schedl A. The WTX/AMER1 gene family: evolution, signature and function. BMC Evol Biol. 2010;10:280.

56. Chen Z, Yao Y, Ma P, Wang Q, Pan Y. Haplotype-based genome-wide association study identifies loci and candidate genes for milk yield in Holsteins. PLoS One. 2018;13:e0192695.

57. Higgins MG, Fitzsimons C, McClure MC, McKenna C, Conroy S, Kenny DA, et al. GWAS and eQTL analysis identifies a SNP associated with both residual feed intake and GFRA2 expression in beef cattle. Sci Rep. 2018:8:14301.

58. Grilz-Seger G, Drum T, Neuditschko M, Dobretsberger M, Horna M, Brem G. High-resolution population structure and runs of homozygosity reveal the genetic architecture of complex traits in the Lipizzan horse. BMC Genomics. 2019;20:174.

59. Grilz-Seger G, Neuditschko M, Ricard A, Velie B, Lindgren G, Mesarič M, et al. Genome-wide homozygosity patterns and evidence for selection in a set of European and near Eastern horse breeds. Genes (Basel). 2019;10:491. 
60. Tskhovrebova L, Trinick J. Making muscle elastic: the structural basis of myomesin stretching. PLoS Biol. 2012;10:e1001264.

61. da Silva Diniz WJ, Lehmann Coutinho L, Tizioto PC, Mello Cesar AS, Gromboni CF, Araújo Nogueira AR, et al. Iron content affects lipogenic gene expression in the muscle of Nelore beef cattle. PLoS One. 2017;11:e016116.

62. de Toro-Martín J, Guénard F, Rudkowska I, Lemieux S, Couture P, Vohl MC. A common variant in ARHGEF10 alters delta- 6 desaturase activity and influence susceptibility to hypertriglyceridemia. J Clin Lipidol. 2018;12:311-20

63. Schiavo G, Bertolini F, Utzeri VJ, Ribani A, Geraci C, Santoro L, et al. Taking advantage from phenotype variability in a local animal genetic resource: identification of genomic regions associated with the hairless phenotype in Casertana pigs. Anim Genet. 2018;49:321-5.

64. Glatzer S, Merten NJ, Dierks C, Wöhlke A, Philipp U, Distl O. A single nucleotide polymorphism within the interferon gamma receptor 2 gene perfectly coincides with polledness in Holstein cattle. PLoS One. 2013:8:e67992.

65. Stafuzza NB, de Oliveira Silva RM, Peripolli E, Bezerra LAF, Lôbo RB, de Ulhoa MC, et al. Genome-wide association study provides insights into genes related with horn development in Nelore beef cattle. PLoS One. 2018;13:e0202978.

66. Liu WB, Liu J, Liang CN, Guo X, Bao PJ, Chu M, et al. Associations of single nucleotide polymorphisms in candidate genes with the polled trait in Datong domestic yaks. Anim Genet. 2014;45:138-41.

67. Butty AM, Frischknecht M, Gredler B, Neuenschwander S, Moll J, Bieber A, et al. Genetic and genomic analysis of hyperthelia in Brown Swiss cattle. J Dairy Sci. 2017;100:402-11.

68. Dai W, Wang Q, Zhao F, Liu J, Liu H. Understanding the regulatory mechanisms of milk production using integrative transcriptomic and proteomic analyses: improving inefficient utilization of crop by-products as forage in dairy industry. BMC Genomics. 2018;19:403.

69. Zhou C, Li C, Cai W, Liu S, Yin H, Shi S, et al. Genome-wide association study for milk protein composition traits in a Chinese Holstein population using a single-step approach. Front Genet. 2019;10:72.

70. Weller MMDCA, Fonseca I, Sbardella AP, Pinto ISB, Viccini LF, Brandão $\mathrm{HM}$, et al. Isolated perfused udder model for transcriptome analysis in response to Streptococcus agalactiae. J Dairy Res. 2019;86:307-14.

71. Makina SO, Muchadeyi FC, van Marle-Köster E, Taylor JF, Makgahlela ML, Maiwashe A. Genome-wide scan for selection signatures in six cattle breeds in South Africa. Genet Sel Evol. 2015;47:92.

72. Bertolini F, Figuereido Cardoso T, Marras G, Nicolazzi EL, Rotschild MF, Amills M, et al. Genome-wide pattern of homozygosity provide clues about the population history and adaptation of goats. Genet Sel Evol. 2018;50:59.

73. Brito LF, Kijas JW, Ventura RV, Sargolzaei M, Porto-Neto LR, Cánovas $A$, et al. Genetic diversity and signatures of selection in various goat breeds revealed by genome-wide SNP markers. BMC Genomics. 2017;18:229.

74. Mastrangelo S, Tolone M, Sardina MT, Sottile G, Sutera AM, Di Gerlando $\mathrm{R}$, et al. Genome-wide scan for runs of homozygosity identifies potential candidate genes associated with local adaptation in Valle del Belice sheep. Genet Sel Evol. 2017:49:84.

75. Ferenčaković M, Sölkner J, Curik I. Estimating autozygosity from highthroughput information: effects of SNP density and genotyping errors. Genet Sel Evol. 2013;45:42.

76. Peripolli E, Stafuzza NB, Prado Munari D, Ferreira Lima AL, Irgang R, Machado MA, et al. Assessment of runs of homozygosity islands and estimates of genomic inbreeding in Gyr (Bos indicus) dairy cattle. BMC Genomics. 2018;19:34.

77. Pérez-Pardal L, Chen S, Costa V, Liu X, Carvalheira J, Beja-Pereira A. Genomic differentiation between swamp and river buffalo using a cattle high-density single nucleotide polymorphisms panel. Animal. 2018;12:464-71.

78. Nandolo W, Utsunomiya YT, Mészáros G, Wurzinger M, Khayadzadeh N, Torrecilha RBP, et al. Misidentification of runs of homozygosity islands in cattle caused by interference with copy number variation or large intermarker distances. Genet Sel Evol. 2018;50:43.

79. MacLeod IM, Meuwissen THE, Hayes BJ, Goddard ME. A novel predictor of multilocus haplotype homozygosity: comparison with existing predictors. Genet Res (Camb). 2009;91:413-26.
80. Brüniche-Olsen A, Kellner KF, Anderson CJ, DeWoody JA. Runs of homozygosity have utility in mammalian conservation and evolutionary studies. Conserv Genet. 2018;2018(19):1295-307.

81. Zhang Y, Vankan D, Zhang Y, Barker JSF. Genetic differentiation of water buffalo (Bubalus bubalis) populations in China, Nepal and south-east Asia: inferences on the region of domestication of the swamp buffalo. Anim Genet. 2011;42:366-77.

82. Cockrill W. The husbandry and health of the domestic buffalo. Rome: Food and Agriculture Organization of the United Nations; 1974.

83. Malhado CH, Malhado AC, Carneiro PL, Ramos AA, Carrillo JA, Pala A. Inbreeding depression on production and reproduction traits of buffaloes from Brazil. Anim Sci J. 2012;84:289-95.

84. Martikainen K, Sironen A, Uimari P. Estimation of intrachromosomal inbreeding depression on female fertility using runs of homozygosity in Finnish Ayrshire cattle. J Dairy Sci. 2018;101:11097-107.

85. Moioli B, Georgoudis A, Napolitano F, Catillo G, Giubilei E, Ligda C, et al. Genetic diversity between Italian, Greek and Egyptian buffalo populations. Livest Prod Sci. 2001;70:203-11.

86. Hossein-Zadeh NG. Analysis of population structure and genetic variability in Iranian buffaloes (Bubalus bubalis) using pedigree information. Anim Prod Sci. 2015;56:1130-5.

87. Zhang Y, Colli L, Barker JSF. Asian water buffalo: domestication, history and genetics. Anim Genet. 2020;51:177-91.

88. Uffo O, Martínez N, Acosta A, Sanz A, Martín-Burriel I, Osta R, et al. Analysis of microsatellite markers in a Cuban water buffalo breed. J Dairy Res. 2017;84:289-92.

89. Kumar B, Kumar Sahoo A, Kumar Ray P, Chandran PC, Taraphder S, Kumar Das A, et al. Evaluation of environmental heat stress on physical and hormonal parameters in Murrah buffalo. J Anim Health Prod. 2019;7:21-4.

90. Ratnakaran AP, Sejian V, Jose VS, Vaswani S, Bagath M, Krishnan G, et al. Behavioral responses to livestock adaptation to heat stress challenges. Asian J Anim Sci. 2017;11:1-13.

91. Mirkena T, Duguma G, Haile A, Tibbo M, Okeyo AM, Wurzinger M, et al. Genetics of adaptation in domestic farm animals: a review. Livest Sci. 2017;132:1-12.

92. Peripolli E, Reimer C, Ha NT, Geibel J, Machado MA, do Carmo Panetto $\mathrm{JC}$, et al. Genome-wide detection of signatures of selection in indicine and Brazilian locally adapted taurine cattle breeds using wholegenome re-sequencing data. BMC Genomics. 2020;21:624.

93. Hailleselasse Sene K, Porter CJ, Palidwor G, Perez-Iratxeta C, Muro EM, Campbell PA, et al. Gene function in early mouse embryonic stem cell differentiation. BMC Genomics. 2007;8:85.

94. de Araujo Neto FR, de Abreu Santos DJ, Fernandes Júnior GA, Aspilcueta-Borquis RR, do Nascimento AV, de Oliveira Seno L, et al. Genome-wide association studies for growth traits in buffaloes using the single step genomic BLUP. J Appl Genet. 2019;18:113-5.

95. Santana MHA, Gomes RC, Utsunomiya YT, Neves HHR, Novais FJ, Bonin $\mathrm{MN}$, et al. Genome-wide association with residual body weight gain in Bos indicus cattle. Genet Mol Res. 2015;14:5229-33.

96. Cai Z, Guldbrandtsen B, Lund MS, Sahana G. Prioritizing candidate genes for fertility in dairy cows using gene-based analysis, functional annotation and differential gene expression. BMC Genomics. 2019;20:255.

97. Jiang J, Cole JB, Freebern E, Da Y, VanRaden PM, Ma L. Functional annotation and Bayesian fine-mapping reveals candidate genes for important agronomic traits in Holstein bulls. Commun Biol. 2019;2:212.

98. McGovern SP, Purfield DC, Ring SC, Carthy TR, Graham DA, Berry DP. Candidate genes associated with the heritable humoral response to Mycobacterium avium ssp. paratuberculosis in dairy cows have factors in common with gastrointestinal diseases in humans. J Dairy Sci. 2019;2019(102):4249-63.

99. Marques DBD, Bastiaansen JWM, Broekhuijse MLWJ, Lopes MS, Knol EF, Harlizius B, et al. Weighted single-step GWAS and gene network analysis reveal new candidate genes for semen traits in pigs. Genet Sel Evol. 2018;50:40.

100. Jakobsen M, Kracht SS, Esteso G, Cirera S, Edfors I, Archibald AL, et al. Refined candidate region specified by haplotype sharing for Escherichia coli F4ab/F4ac susceptibility alleles in pigs. Anim Genet. 2010;41:21-5. 
101. Zhou C, Liu Z, Liu Y, Fu W, Ding X, Liu J, et al. Gene silencing of porcine MUC13 and ITGB5: candidate genes towards Escherichia coli F4ac adhesion. PLoS One. 2013;8:e70303.

102. Patel S, Alvarez-Guaita A, Melvin A, Rimmington D, Dattilo A, Miedzybrodzka EL, et al. GDF15 provides an endocrine signal of nutritional stress in mice and humans. Cell Metab. 2019;29:707-18.

103. Bonnefont CMD, Toufeer M, Caubet C, Foulon E, Tasca C, Aurel MR, et al. Transcriptomic analysis of milk somatic cells in mastitis resistant and susceptible sheep upon challenge with Staphylococcus epidermidis and Staphylococcus aureus. BMC Genomics. 2011;12:208.

104. Al Kalaldeh M, Gibson J, Lee SH, Gondro C, van der Werf JHJ. Detection of genomic regions underlying resistance to gastrointestinal parasites in Australian sheep. Genet Sel Evol. 2019;51:37.

105. Kim KS, Seibert JT, Edea Z, Graves KL, Kim ES, Keating AF, et al. Characterization of the acute heat stress response in gilts: III. Genome-wide association studies of thermotolerance traits in pigs. J Anim Sci. 2018;96:2074-85.

106. Carty $\mathrm{CL}$, Johnson NA, Hutter $\mathrm{CM}$, Reiner $\mathrm{AP}$, Peters $\mathrm{U}$, Tang $\mathrm{H}$, et al. Genome-wide association study of body height in African Americans: the Women's Health Initiative SNP Health Association Resource (SHARe). Hum Mol Genet. 2012;21:711-20.

107. Sasaki S, Ibi T, Akiyama T, Fukushima M, Sugimoto Y. Loss of maternal ANNEXIN A10 via a 34-kb deleted-type copy number variation is associated with embryonic mortality in Japanese Black cattle. BMC Genomics. 2016;17:968.
108. Wang X, Miao J, Xia J, Chang TGE, Bao J, Jin SY, et al. Identifying novel genes for carcass traits by testing $G \times E$ interaction through genomewide meta-analysis in Chinese Simmental beef cattle. Livest Sci. 2018;212:75-82.

109. Narahara S, Sakai E, Kadowaki T, Yamaguchi Y, Narahara H, Okamoto K, et al. KBTBD11, a novel BTB-Kelch protein, is a negative regulator of osteoclastogenesis through controlling Cullin3-mediated ubiquitination of NFATc1. Sci Rep. 2019;9:3523.

110. Lisik W, Tejpal N, Gong Y, Skelton TS, Ganachari M, Bremer EG, et al. Down regulation of genes involved in T cell polarity and motility during the induction of heart allograft tolerance by allochimeric MHC I. PLoS One. 2008:4:e8020.

111. Rasmussen AH, Rasmussen HB, Silahtaroglu A. The DLGAP family: neuronal expression, function and role in brain disorders. Mol Brain. 2017;10:43.

112. Kraus DM, Elliott GS, Chute H, Horan T, Pfenninger KH, Sanford SD, et al. CSMD1 is a novel multiple domain complement-regulatory protein highly expressed in the central nervous system and epithelial tissues. J Immunol. 2006;176:4419-30.

\section{Publisher's Note}

Springer Nature remains neutral with regard to jurisdictional claims in published maps and institutional affiliations.
Ready to submit your research? Choose BMC and benefit from:

- fast, convenient online submission

- thorough peer review by experienced researchers in your field

- rapid publication on acceptance

- support for research data, including large and complex data types

- gold Open Access which fosters wider collaboration and increased citations

- maximum visibility for your research: over $100 \mathrm{M}$ website views per year

At BMC, research is always in progress.

Learn more biomedcentral.com/submissions 